Article

\title{
Environmental Dynamics of the Ribbon-Like Pine Forests in the Parklands of North Kazakhstan
}

\author{
Sholpan Zhumadina ${ }^{1}\left(\mathbb{D}\right.$, Jiri Chlachula ${ }^{2,3, *(\mathbb{D})}$, Alina Zhaglovskaya-Faurat ${ }^{4}$ (D), Jolanta Czerniawska ${ }^{2}$, \\ Gulmira Satybaldieva ${ }^{5}$, Nailya Nurbayeva ${ }^{5}\left(\mathbb{D}\right.$, Nariman Mapitov ${ }^{6}$, Anar Myrzagaliyeva ${ }^{7}$ \\ and Elmira Boribay ${ }^{8}$ (D)
}

check for updates

Citation: Zhumadina, S.; Chlachula, J.;

Zhaglovskaya-Faurat, A.;

Czerniawska, J.; Satybaldieva, G.; Nurbayeva, N.; Mapitov, N.;

Myrzagaliyeva, A.; Boribay, E.

Environmental Dynamics of the

Ribbon-Like Pine Forests in the

Parklands of North Kazakhstan.

Forests 2022, 13, 2. https://doi.org/

10.3390/f13010002

Academic Editors: Carolina

Martínez-Ruiz and Josu G. Alday

Received: 29 October 2021

Accepted: 16 December 2021

Published: 21 December 2021

Publisher's Note: MDPI stays neutral with regard to jurisdictional claims in published maps and institutional affiliations.

Copyright: (c) 2021 by the authors. Licensee MDPI, Basel, Switzerland. This article is an open access article distributed under the terms and conditions of the Creative Commons Attribution (CC BY) license (https:// creativecommons.org/licenses/by/ $4.0 /)$.
1 Department of Biology, Saken Seifullin Kazakh Agrotechnical University, Nur-Sultan 010011, Kazakhstan; ms.zhumadina@mail.ru

2 Institute of Geoecology and Geoinformation, Adam Mickiewicz University, 61-680 Poznan, Poland; jolczer@amu.edu.pl

3 Environmental Research Centre, 68603 Stare Mesto, Czech Republic

4 Department of Geography and Tourism, Toraighyrov University, Lomov Street 64, Pavlodar 140008, Kazakhstan; alina03.09@mail.ru

5 Department of Ecology, Saken Seifullin Kazakh Agrotechnical University, Nur-Sultan 010011, Kazakhstan; gkalmashevna@mail.ru (G.S.); nnurbaeva1956@mail.ru (N.N.)

6 Department of Biology and Ecology, S. Toraighyrov State University, Pavlodar 140008, Kazakhstan; mapitov@mail.ru

7 Higher School of Natural Sciences, Astana International University, Nur-Sultan 010000, Kazakhstan; anara_vkgu@mail.ru

8 Department of Ecology, Narxoz University, st. Dzhandosova, 55, Almaty, Almaty 050040, Kazakhstan; eboribai_71@mail.ru

* Correspondence: paleo@amu.edu.pl or Altay@seznam.cz

\begin{abstract}
The ribbon-like pine forests of North Kazakhstan represent the principal territorial intrazonal and azonal biotopes. Integrated bio-geographic studies of the pine forests' status were performed in the Beskaragai and Chaldai Nature Reserves in the Pri-Irtysh River basin within, at present, the climate-change most susceptible transitional parkland-steppe zone of Central Asia, adjoining the West Siberian Lowland. The investigations followed the regional topographic gradient with a series of mapped sites characterizing the spatial relief patterns of the pristine forest distribution and the associated phytocenoses. The results revealed marked natural arboreal cover restoration differences between the geographically close upland and lowland forest ecosystems. The regional tree growth dynamics show the varying intensity of the pine seedlings' succession, the tree stands' biomass productivity and the environmental stability, weakened by the extreme continentality and progressing aridification along with adverse anthropogenic ecological impacts. The specific geomorphic, soil and hydrological conditions are the principal determining factors. The more vital plain and lowland pine forests host the floristically richer fescue-dominated communities compared to the more fragile and precipitation-poorer upland pine settings. The latter forest ecosystems display a higher vulnerability to the current climate change, generating tree drying, forest fires, and to modern human activities such as logging, herding and recreation. The research conclusions provide new insights on the natural ribbon-like pine forests' sustainability and adaptation to the ongoing continental warming triggering fundamental environmental transformations in Central Asia's parklands.
\end{abstract}

Keywords: Kazakhstan; parkland-steppes; ribbon-like pine forests; arboreal cover; degradation; climate change; aridification; environmental conservation; biodiversity; sustainability

\section{Introduction}

The Republic of Kazakhstan is one of the least-forested countries. The present forest cover amounts to $<5 \%$ [1]. The main arboreal resources are located in the northeastern and southeastern parts of the country. These areas include mountain/alpine forests of the Altai 
and the Tien Shan ranges, floodplain forests, haloxylon deserts, as well as forests growing in the forest-steppe and the steppe zone of the northern, sandy plains of the Irtysh River basin [2-4]. The plain forests and forests of the Central Kazakhstan Hills (Mel'kosopochnik) are located in several vegetation zones. The pine forests are represented by small island arrays and outliers among vast treeless spaces, the natural ribbon pine forests and artificial plantings that grow along isolated hills in deserts and on floodplains [5,6]. In the northern and northeastern regions, the Scots Pine (Pinus sylvestris L.) forests got preserved as Pleistocene ecosystem relics; locally, these forests constitute the principal arboreal cover. The Last Glacial forest-steppe landscapes stretched more extensively along the northern periglacial zone of western Siberia from the Urals in the West to the Altai foothills in the East $[7,8]$. The present steppe forests are intrazonal and azonal vegetation types [9].

Pine forests provide an important source of information about the past (centuries-long) natural dynamics in Northern Kazakhstan. Currently, the local arboreal cover fulfills the most important environmental and regional climate stabilizing function contributing to the sustainment of hydrological conditions of the territory, including a seasonal surface runoff, supplying the arid-zone riverine network and steppe lake systems [10]. The broader regional environmental transformations encompassing the Kazakh-Russian border zone (Figure 1A) have not, until now, been sufficiently investigated and remained limited to just a few pilot studies [11-17], in contrast to the eastern mountain areas [18,19]. In addition, ribbon-like pine forests growing on sandy soils are of a great soil-protective significance, reducing sediment transfer and slowing down progressing aeolian erosion. Finally, the local parkland forest ecosystems contribute to the microclimate and sustainability of animals as well as humans.

The degradation of the forest ecosystems is a well discussed global environmental issue as well as a political issue. There are many definitions of forest degradation $[20,21]$, but none of them take into account all factors. The arboreal cover reduction has been described using the regionally specific variables such as changes in the tree crowns and the undergrowth, as well as in the richness of plant and animal species and/or the total carbon stocks from the baseline, i.e., from the presumed intact pristine natural conditions [22-24]. The ongoing forests degradation around the world shows various trajectories in terms of time, space and scale $[25,26]$. In northern Kazakhstan and the adjacent part of SW Siberia, a certain influence of the present climatic factors on the Scotch pine tree growth based on tree ring studies is presumed $[27,28]$.

At present, most of the forests on the territory of Kazakhstan are subjected to a different degree of environmental threat because of excessive human activities (deforestation, herding, burning), progressing aridification and wildfires [29]. Due to these long-term negative ecological trends accentuated by the most dynamic warming increase in the March and August months [30], preservation of the remaining forest cover in the country is of utmost importance. This requires research and monitoring of the main environmental factors affecting the state of the forest biotopes over the extensive, yet discontinuously wooded eastern parklands extending northwards into the Siberian mixed taiga belt by up to 350-400 km. As the process of deforestation and the mean annual air temperature (MAAT) rise over the territory intensifies [31], new problems of sustainability and biodiversity conservation of pine forests arise. Complex studies of the regularities of the vegetation dynamics, the identification of its anthropogenic degradation and the planning of measures for rational use and protection are needed. The research implications are relevant to other regions with similar ecological (climatic, geomorphic, biotic and anthropogenic) conditions $[32,33]$. The forest cover preservation, rehabilitation and protection in Kazakhstan are the state's environmental policy priorities [34].

The paper presents results of the spatial analysis of abiotic and biotic factors related to the pristine pine forest dynamics and the arboreal cover preservation in the Beskaragai and Chaldai nature protection areas. It discusses the main environmental aspects affecting the forest growth in the Irtysh basin following investigations between 2015-2021. For the first time, an integral geo-contextual and botany study of the coniferous ecosystems of North 
Kazakhstan was carried out. The goal was to provide a close assessment of the present forest growth and the floristic structure of the surrounding parkland-steppes exposed to different impacts (natural vs. anthropogenic), and their effective regional preservation under ongoing climate change leading to the more pronounced continentality and the territorial landscape dryness.

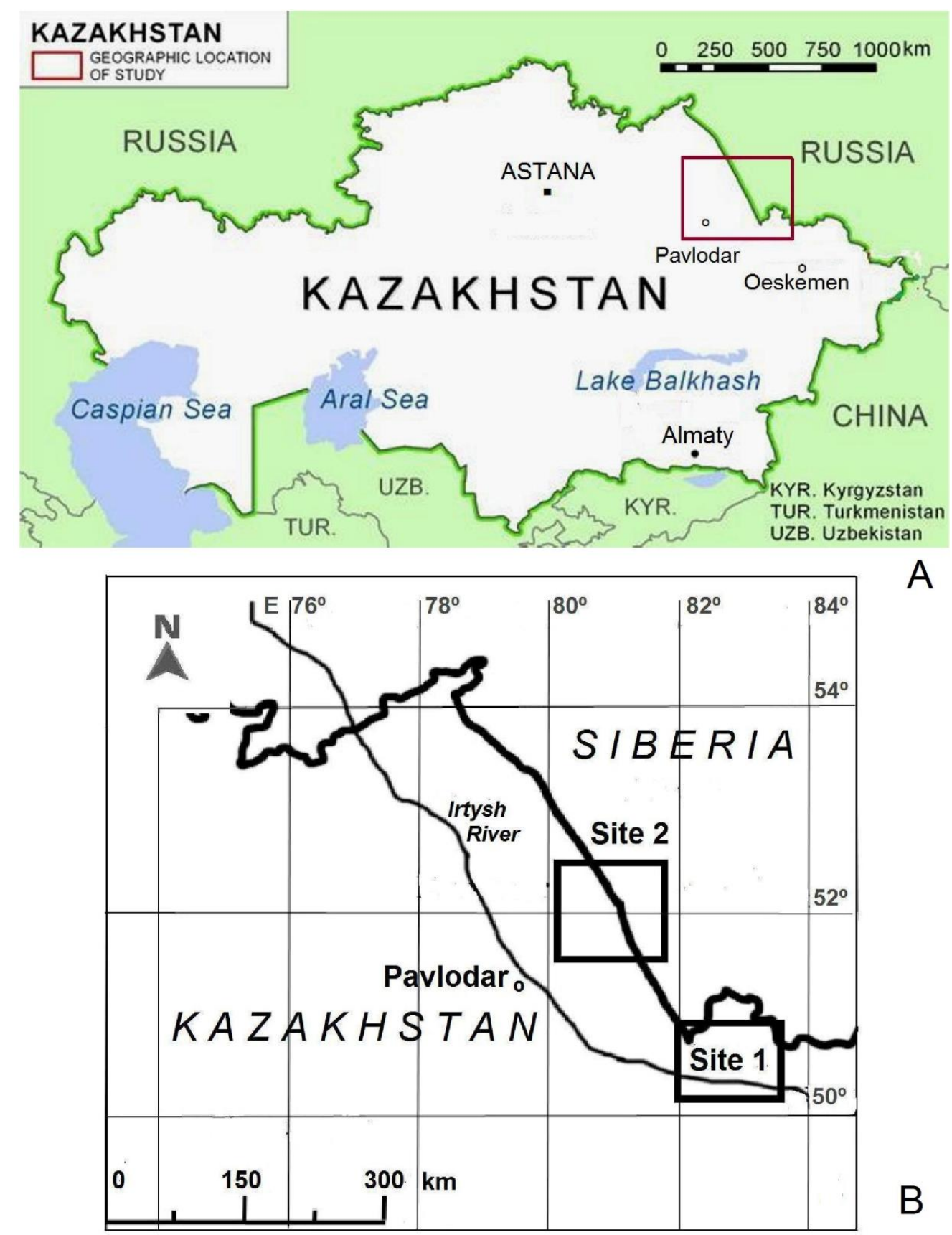

Figure 1. (A) The geographical location of the study area in NE Kazakhstan along the Russian (West Siberian) border. (B) Location of the two investigated sites in the Beskaragai and Chaldai Nature Reserves, respectively.

\section{Materials and Methods}

\subsection{Study Area}

The ribbon-like pines in NE Kazakhstan (Figure 1A) and the adjoining West Siberia occupy narrow geomorphic depressions of the former (Late Pleistocene) glacial runoff storage basins [35]. These forests are more large-scale phenomena in the adjoining SW 
Siberia (the Kulunda Steppe and the Altai Plains), forming narrow NE-SW oriented strips of forests (mostly of Pinus sibirica Du Tour) growing on glacio-fluvial sands of the last glaciation $[36,37]$. The studied ribbon-like pine forests are located in the southeastern and northern parts of the Pavlodar Region and the Semipalatinsk Region, respectively, of the Irtysh (Pri-Irtysh) sandy plain area (Figure 1B). The natural arboreal cover is characterized by light-colored conifers distributed in the geographically W-E extended parkland foreststeppe and steppe belts. Due to the interaction of the fluvial and aeolian landscapeforming processes, the top surface of the aquatic runoff troughs acquired a dune-like hilly (hummocky) relief blanketed by early Holocene wind-blown sands. These loose deposits create a natural basement of the pine forests separated by patches of grasslands. Pine (Pinus sylvestris L.) constitutes $70-90 \%$ of the regional arboreal cover. The present distribution of the conifers extends from the SW to the NE for $\sim 550 \mathrm{~km}$ with a width of 5-40 km by intersecting several bioclimatic subzones: dry steppe, arid steppe, moderately arid steppe, southern and middle forest-steppe [38,39].

The pristine ribbon-like pine forests began to be intensively cut following the initial industrialization (mining and construction) in the early 18th century during the expansion of the Russian Empire. In the 19th century, uncontrolled logging took place, the scale of which became reduced during the 20th century. This was in part due to the creation of several protected natural areas in North Kazakhstan during the Soviet times, including two state forest reserves and the Bayanaul National Park. Despite this, excessive (partly illegal) logging along with vegetation burning, mining of sand for construction, and increasing recreational pressure are causing a progressive deterioration of the forested lands, including those under state protection. These anthropogenic risks along with the impacts of present climate warming adversely affect the natural regeneration functions of the regional pine forests, and lead to transformation and degradation of the forested landscape replaced by zonal (parkland) steppes and semi-desert grasslands [40,41].

The intra-continental semi-arid forest ecosystems of the Irtysh basin geographically encompass the sandy-base forests of the Semey-Orman Nature Reserve (Site 1-Beskaragai) and the Hertis-Orman Nature Reserve (Site 2-Chaldai) of the Pavlodar Region (Figure 2). These steppe pine forests are situated on sandy alluvial plains around the confluence of the $\mathrm{Ob}$ and Irtysh Rivers forming the principal territorial discharge network of SW Siberia. The plains are geologically structured by quartz-dominated sandy-gravels blanketed by silty-clayey overbank deposits. The adjoining elevated relief $(250-600 \mathrm{~m}$ asl) is built by the chains of weathered granitic and limestone hills interspersed by flat to undulating plains and small geomorphic depressions. The present climate is strongly continental with pronounced daily temperature fluctuations. Arid springs and hot summers (with temperatures of up to $+45^{\circ} \mathrm{C}$ ) contrast with relatively wet falls and cold, dry winters (with temperatures down to $-45^{\circ} \mathrm{C}$ ). The average annual rainfall amounts to $250-300 \mathrm{~mm}$.

The investigated territory of the ribbon pine forest nature reserves is located in the subzone of the feather-fescue steppes in the Irtysh-Ob pine- and birch-dominated parklands. The zonal soils developed under the forest cover have a predominantly light mechanical sandy silt structure underlain by compact and poorly percolating saline tertiary clays. Luvisolic soils occur in the seasonally watered/waterlogged low-elevation depressions. Meadow chestnut soils are occasionally found in otherwise arid plains with a high evaporation rate. 

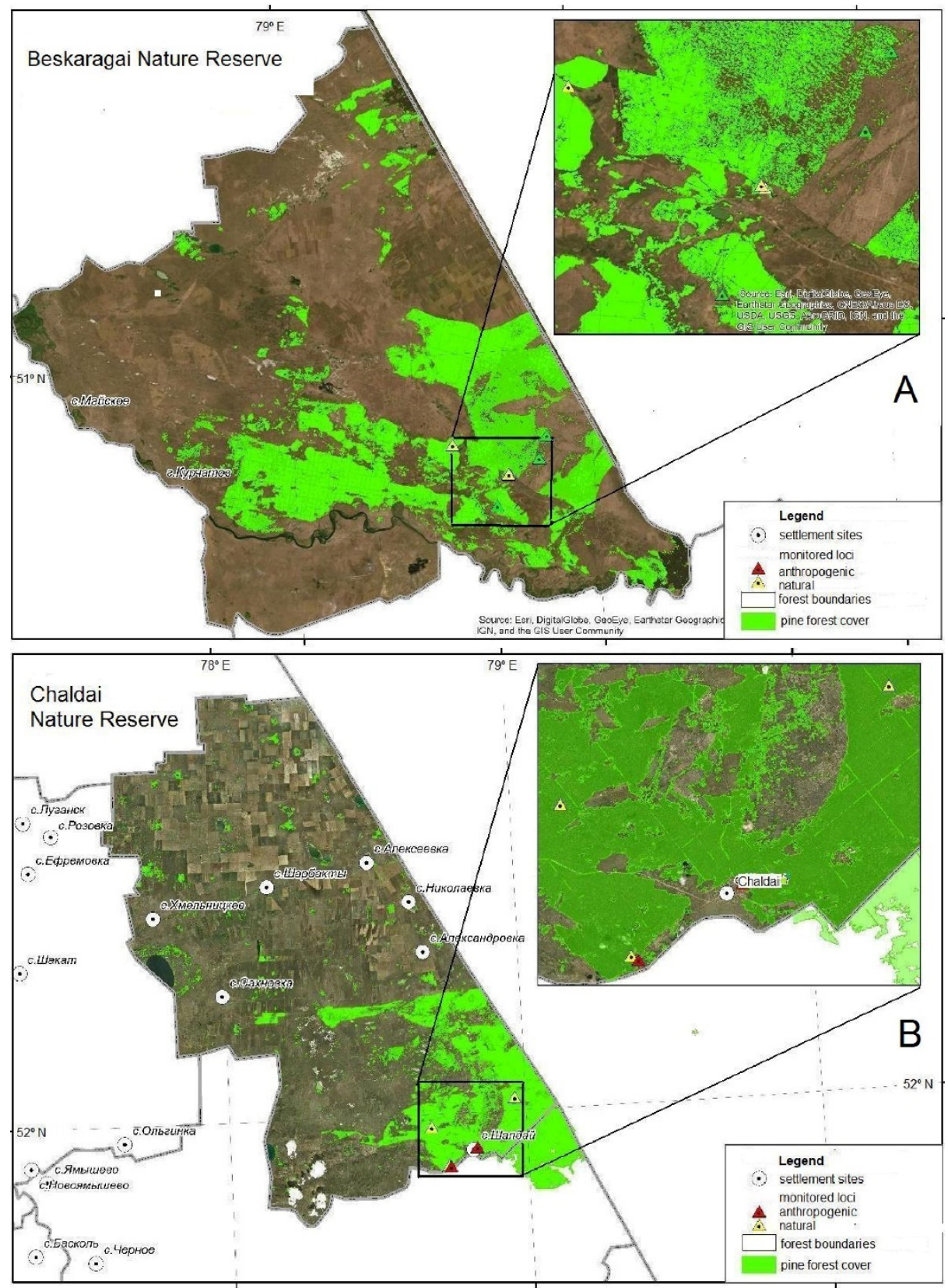

Figure 2. GIS vegetation cover projection of the distribution of the pine forests in the Beskaragai (A) and Chaldai (B) Nature Reserves.

\subsection{Geo-Ecological Landscape Profiles}

The research aim was to document and assess the state of the NE Kazakhstan pine forests in the transitional and environmentally susceptible parkland-steppe zone in relation to the natural habitats under the current aridification. The complex study included the determinant taxonomic bio-geographic characteristics, floristic composition and evaluation of the pine stocks' restoration potential with an estimation of the future forest degradation. Investigation of the particular forest-parkland vegetation communities under the regionally specific conditions followed two principal geo-ecological profiles in the Semey-Orman and the Hertis-Orman Nature Reserves (the Beskaragai-Site 1 and Chaldai-Site 2, respectively). The geo-ecological profile (transect) represents a linear land strip cutting the area with changing site complexes, characterized by the specific biotic and abiotic factors. The transected landscape is defined by the relief (altitude, geo-forms, bedrock), hydrology, soil cover, forest type and its agro-physical characteristics. 


\subsection{Fieldwork and Data Analyses}

The fieldwork included arboreal and geobotanical studies with standard mapping of the forest ecosystems [42-44]. At the two principal loci (Beskaragai and Chaldai), 500 trees per site/test plot (TP) were documented at the typical geomorphic and hydrological settings. The TPs were set up to form linear transects across the sites, each defined by the specific environmental characteristics. For each mapped TP, 50 trees were selected using the PSQ (point centered quarter) method [43]. The vegetation structure was determined by the floristic phytocenosis and a herbarium collection with an on-site and a closer laboratory taxonomic identification [45].

Zonality in the forest phytocenoses was determined according to the present life forms. The floristic communities were separately described in four vegetation layers: woody, shrub, grass-and-shrub and moss-and-lichen. The formula of the growing local stock composition was determined using the percentages or equity participation of the specific arboreal species. The individual forest site capacity was evaluated according to the average height and the age of the stand. The tree crown size and density were visually assessed. The age of mature trees was determined by the dendrochronological method using the Presler drill. The width of the growth rings was measured with the accuracy of "+ / -" $0.01 \mathrm{~mm}$ on the LINTAB-6.0 semi-automatic installation [46]. The value of the width of the growth rings was fixed by the computer program TSAP-Win. The age of the conifer seedlings and undergrowth was estimated by one-year whorl (verticil). The height of the trees was measured by a hypsometer, altimeter, or assessed visually at the less accessible places. The diameter of the tree trunks was determined by a measuring fork at a height of $1.3 \mathrm{~m}$. Forest densities were calculated, with the basal area defined as the total of all stems per land unit [47]. The cover (\%) of each plant species was determined visually and classified in terms of the taxonomical group and ecological vitality; the concentration of plants and herbs was measured as a percentage of the total TP area:

Basal area $=\mathrm{A} \times \frac{\text { Density }}{\text { ha }} \times \frac{1 \mathrm{~m}^{2}}{10.000 \mathrm{~cm}}$, where $\mathrm{A}$ is the basal area of tree $\left[\mathrm{cm}^{2}\right] . \mathrm{A}=\pi \mathrm{d}^{2} / 4$, where $\mathrm{d}$ is the diameter of tree trunk $[\mathrm{cm}]$.

Forest density $=\sum \sum_{\mathrm{d}} \mathrm{G}_{\mathrm{h}}$, where $\mathrm{G}_{\mathrm{d}}$ is the basal area of tree stands $\left[\mathrm{cm}^{2}\right]$, and $G_{h}$ is the basal area of standard tables $\left[\mathrm{cm}^{2}\right]$ [48].

Crown cover determines the amount of light able to penetrate to the forest floor and it is expressed in tenths of one $(0.9 ; 0.8 ; 0.7 ; 0.6$, etc.). The regeneration number was taken into account at the sites of $100 \mathrm{~m}^{2}(\mathrm{TP}$ of $10 \times 10 \mathrm{~m})$. A calculation of shoots and undergrowth of the Scotch pine was carried out systematically at the monitored sites. Trees with less than half of the height of an adult (grown-up) tree were considered juvenile [49]. For the study of the interacting relationship of the regional vegetation communities and the specific environmental conditions, the regional vegetation cover variability and edaphic elements along the biogeomorphic profile (spatial transect) were used. Statistical field data processing was carried out by the Statistica 7.0 software (2019) and MS Excel.

The spatial vegetation cover assessment was performed using the free global satellite imagery data $[50,51]$ and the civil spacecraft images and the geospatial contents of the Digital Globe, GeoEye-1 (4-Band 30 m resolution data) and Earthstar (2021). Remote sensing data (RSD) provided an important source of information about the natural environment for specific thematic layers of GIS [52]. Decoded archival and modern images of medium (10 m) resolution for the period between 2017-2019 of the "Sentinel-2" (EU) and "Landsat-8" (USA) satellite database were used for the RSD thematic processing on the investigated territory (the Beskaragai, Shcherbaktinsky and Bayanaul Districts). The landscape structure and the vegetation cover composition were modeled by vector data of the forested areas $[53,54]$. Digitization of boundaries of forest resources was carried out in the ArcGIS program using the standard analytical tools [55,56] (Figure 2A,B). 


\section{Results}

\subsection{Pine Forest Habitat Types}

The field studies at the Beskaragai-Site 1 and Chaldai-Site 2 transects conducted at 11 test plots (TP) each, characterized by the specific geomorphologic, geological, hydrological and vegetation conditions, show a certain variability of forest habitats with a differential degree of resilience to environmental stress and degradation of the pine phytocenoses (Table 1).

Table 1. Characteristics of the test plots of the regional geo-environmental transect.

\begin{tabular}{|c|c|c|c|c|c|c|c|}
\hline Plots & Geograph & 1 Location & $\begin{array}{l}\text { Elevation } \\
\text { (m asl) }\end{array}$ & Relief & Forest Type & Soil Cover & $\begin{array}{c}\text { Soil } \\
\text { Moisture } \\
\text { Regime }\end{array}$ \\
\hline \multicolumn{8}{|c|}{ Beskaragai } \\
\hline TP 1 & $50^{\circ} 48^{\prime} 57^{\prime \prime} \mathrm{N}$ & $79^{\circ} 50^{\prime} 53^{\prime \prime} \mathrm{E}$ & 267 & High hill & Dry forest & $\begin{array}{c}\text { Thin sandy } \\
\text { regosols }\end{array}$ & Very dry \\
\hline TP 2 & $50^{\circ} 46^{\prime} 05^{\prime \prime} \mathrm{N}$ & $79^{\circ} 49^{\prime} 04^{\prime \prime} \mathrm{E}$ & 252 & $\begin{array}{l}\text { Gently } \\
\text { rolling hill }\end{array}$ & Dry forest & $\begin{array}{l}\text { Thin sandy } \\
\text { regosols }\end{array}$ & Very dry \\
\hline TP 3 & $50^{\circ} 44^{\prime} 11^{\prime \prime} \mathrm{N}$ & $79^{\circ} 43^{\prime} 00^{\prime \prime} \mathrm{E}$ & 225 & $\begin{array}{l}\text { Upland } \\
\text { plateau }\end{array}$ & Dry forest & $\begin{array}{c}\text { Thin sandy } \\
\text { regosols }\end{array}$ & Very dry \\
\hline TP 4 & $50^{\circ} 44^{\prime} 19^{\prime \prime} \mathrm{N}$ & $79^{\circ} 42^{\prime} 47^{\prime \prime} \mathrm{E}$ & 201 & $\begin{array}{l}\text { Lowland } \\
\text { depression }\end{array}$ & $\begin{array}{l}\text { Semi-arid } \\
\text { forest }\end{array}$ & $\begin{array}{l}\text { Sandy } \\
\text { brunisol }\end{array}$ & Dry \\
\hline TP 5 & $50^{\circ} 40^{\prime} 21^{\prime \prime} \mathrm{N}$ & $79^{\circ} 40^{\prime} 06^{\prime \prime} \mathrm{E}$ & 270 & High hill & $\begin{array}{l}\text { Semi-arid } \\
\text { forest }\end{array}$ & $\begin{array}{l}\text { Sandy } \\
\text { brunisol }\end{array}$ & Dry \\
\hline ТР 6 & $50^{\circ} 48^{\prime} 26^{\prime \prime} \mathrm{N}$ & $79^{\circ} 31^{\prime} 52^{\prime \prime} \mathrm{E}$ & 123 & Rolling plain & $\begin{array}{c}\text { Semi-arid } \\
\text { forest }\end{array}$ & $\begin{array}{l}\text { Sandy } \\
\text { brunisol }\end{array}$ & $\begin{array}{l}\text { Dry/semi- } \\
\text { dry }\end{array}$ \\
\hline \multicolumn{8}{|c|}{ Chaldai } \\
\hline TP 1 & $51^{\circ} 53^{\prime} 26^{\prime \prime} \mathrm{N}$ & $78^{\circ} 44^{\prime} 18^{\prime \prime} \mathrm{E}$ & 162 & Rolling plain & $\begin{array}{l}\text { Plain pine } \\
\text { forest }\end{array}$ & $\begin{array}{l}\text { Sandy } \\
\text { brunisol }\end{array}$ & Dry \\
\hline TP 2 & $51^{\circ} 53^{\prime} 35^{\prime \prime} \mathrm{N}$ & $78^{\circ} 43^{\prime} 57^{\prime \prime} \mathrm{E}$ & 166 & Flat plain & $\begin{array}{l}\text { Plain pine } \\
\text { forest }\end{array}$ & $\begin{array}{l}\text { Sandy } \\
\text { brunisol }\end{array}$ & Semi-arid \\
\hline TP 3 & $52^{\circ} 01^{\prime} 39^{\prime \prime} \mathrm{N}$ & $78^{\circ} 57^{\prime} 46^{\prime \prime} \mathrm{E}$ & 173 & Flat plain & $\begin{array}{l}\text { Plain pine } \\
\text { forest }\end{array}$ & $\begin{array}{l}\text { Sandy } \\
\text { brunisol }\end{array}$ & Semi-humid \\
\hline $\mathrm{TP} 4$ & $51^{\circ} 58^{\prime} 27^{\prime \prime} \mathrm{N}$ & $78^{\circ} 40^{\prime} 44^{\prime \prime} \mathrm{E}$ & 220 & Flat plain & $\begin{array}{l}\text { Plain pine } \\
\text { forest }\end{array}$ & $\begin{array}{l}\text { Sandy } \\
\text { brunisol }\end{array}$ & Semi-arid \\
\hline TP 5 & $51^{\circ} 55^{\prime} 40^{\prime \prime} \mathrm{N}$ & $78^{\circ} 49^{\prime} 47^{\prime \prime} \mathrm{E}$ & 157 & Flat plain & $\begin{array}{l}\text { Plain pine } \\
\text { forest }\end{array}$ & $\begin{array}{l}\text { Sandy } \\
\text { brunisol }\end{array}$ & Semi-arid \\
\hline
\end{tabular}

\subsubsection{Beskaragai Nature Reserve}

The Beskaragai area transect cutting through the Beskaragai ribbon-like pine forest nature protection area extends $20 \mathrm{~km}$ in the SW direction at elevation $200-270 \mathrm{~m}$ asl (Figure 3). The bio-geographic profile displays a change in the local relief following the sequence: elevated hills-gentle hills—undulating plains with a gradual decrease in tree heights (Figure 4A-C). Each element of the geo-relief corresponds to a certain type of forest: dry forest on the highlands, dry forest of the gently rolling hills, dry forest of the hilly western area and lowland forest in the river valleys. The geo-ecological profile of the Beskaragai site is characterized by marked soil-type changes. Depending on the location of the test plot (TP) area, the following pedogenetic types were encountered: loose regosolic sandy soils, poorly developed sandy brunisols, low-podzolized soils [57]. The agro-physical properties of the pedogenic horizons were assessed by the degree of top ground moisture corresponding to the extremely dry to dry soils. 


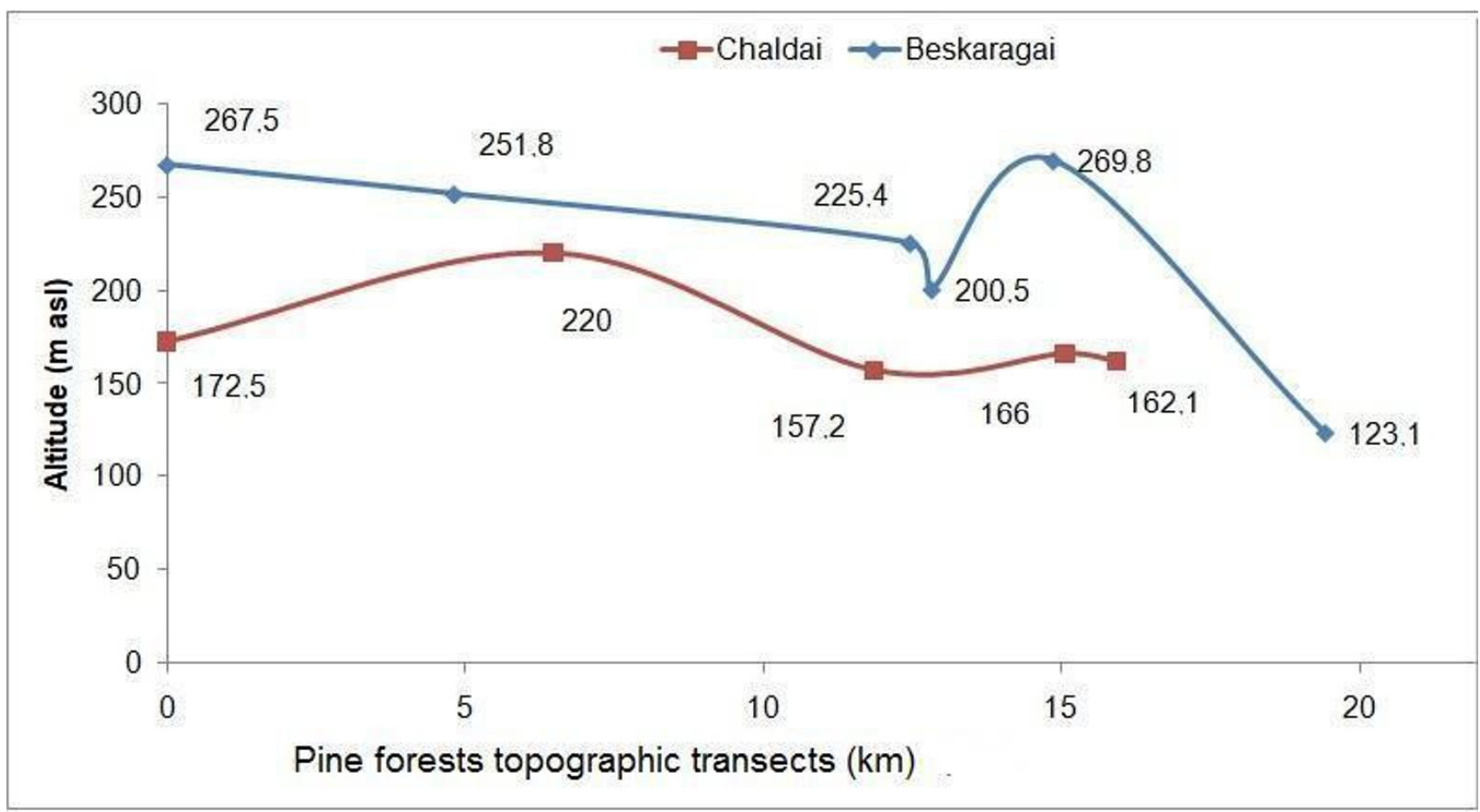

Figure 3. The geomorphic profiles of the investigated areas: the Beskaragai and Chaldai NR.

The dry pine forests bound to the hill lands underlain by loose-sandy, poorly developed regosols are most widely distributed. Single-tier stands together with Scotch pine (Pinus sylvetstris L.) prevail. The tree regeneration is $966 \mathrm{pcs} / \mathrm{ha}$ of young growth and $766 \mathrm{pcs} / \mathrm{ha}$ of seedlings. Mixed Graminae and Cyperaceae vegetation non-arboreal communities (Stipa pennata L., Carex supine Willd. ex Wahlenb.) characterize this pine forest type. The protective grass cover amounts to $\sim 60 \%$; the average height of plants is $30 \mathrm{~cm}$; the communities are mainly two-layer type. The phenological state is represented by plants at the stage of fruit ripening seeds. The soil moisture regime is extremely dry.

The second category, the dry pine forest growth is represented by pine forests on gentle hills and slopes underlain by thin sandy semi-arid brunisols. The vegetation cover encompassing $\sim 65 \%$ is richer in the floral composition with admixed wild cereals; the average height of herbaceous plants is $30 \mathrm{~cm}$; the communities are mainly single-layer type. The moisture regime slightly exceeds the dry pine forest on the high hills. Finally, on the topographically lowest places - the undulating plains - the plain forests are distributed, bound to barren lands with sandy, weakly podzolic and medium-dry soils formed under a semi-arid moisture regime.

\subsubsection{Chaldai Nature Reserve}

The Chaldai transect of the Chaldai Nature Reserve ribbon-like pine forest stretches across a rolling plain relief for $22.5 \mathrm{~km}$ in the SW direction at an elevation of $157-220 \mathrm{~m}$ asl (Figure 3). The particular lowland pine forest types correspond to the particular geomorphic positions (Figure 4D-F) pegodenically associated with the mature parkland-steppe chernozems. The degree of soil moisture balance is dry to semi-dry with the latter contributing to the formation of kashtanozems. The distribution patterns of the Chaldai vegetation communities depend on the varying natural factors established along with the mapped bio-geographic profile.

Three different types of relief define the area-high sandy hills, low hilly deflated surfaces and undulating plains. Under the loci-specific forest-growing conditions of the monitored forest ecosystems, there are apparent differences in the floristic composition of phytocenoses and the agro-physical characteristics of the soil cover (Table 1). 


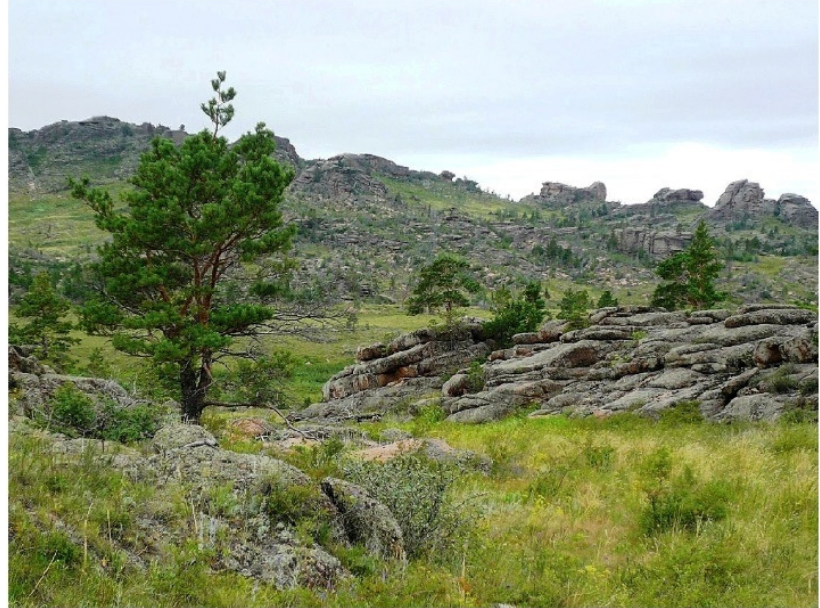

A

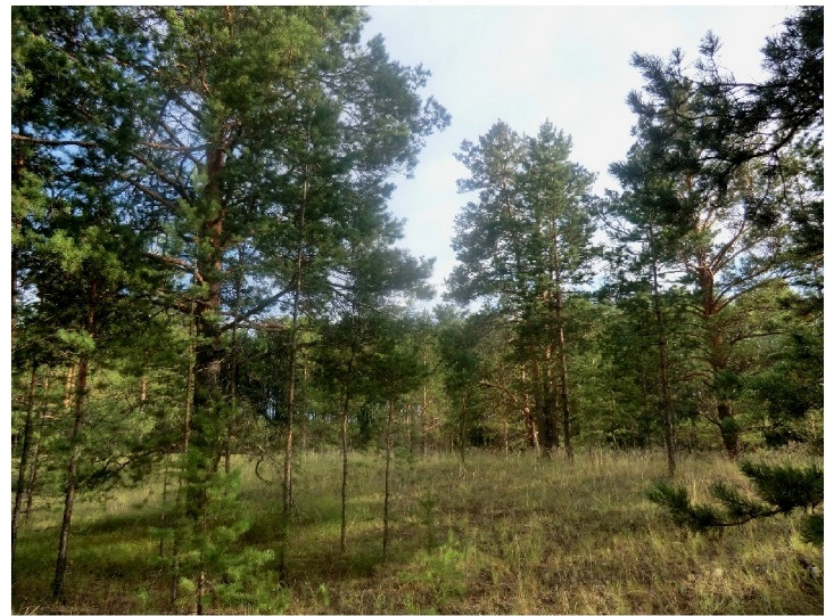

C

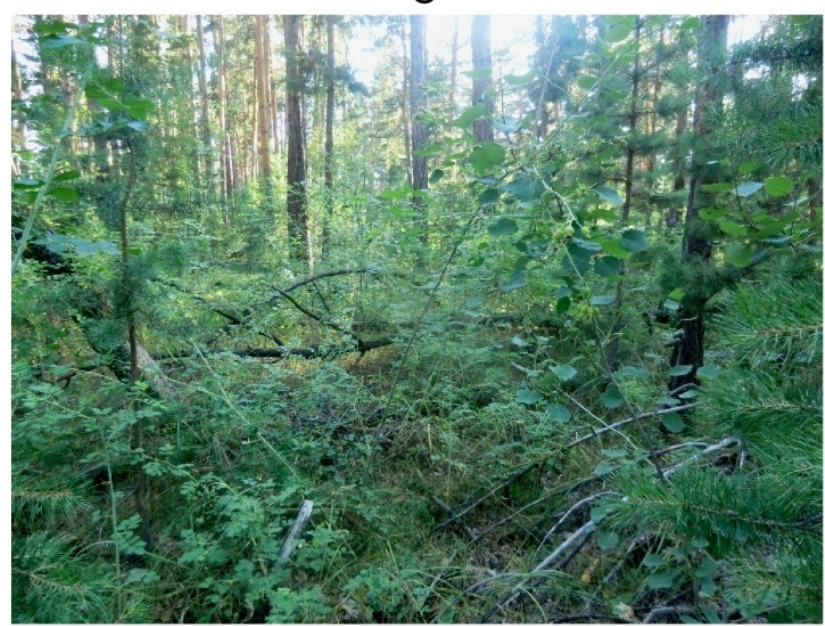

E

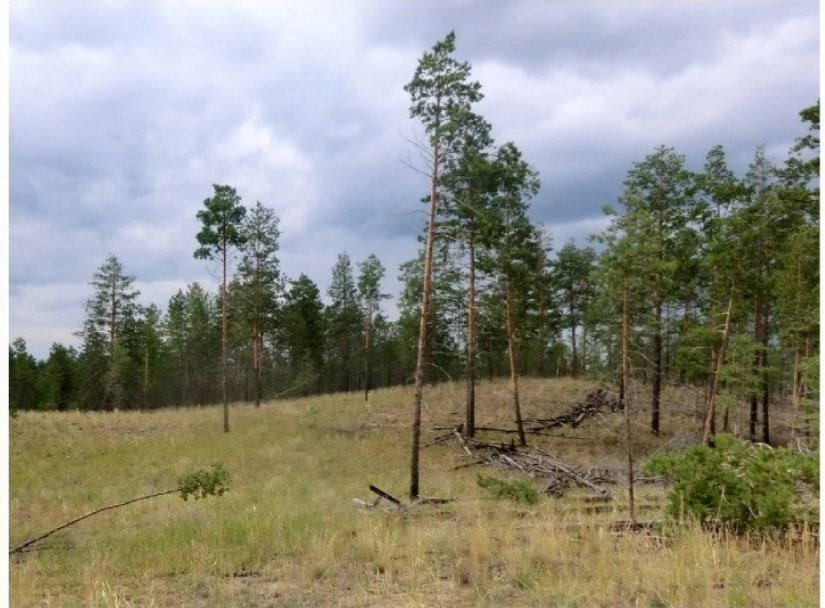

B

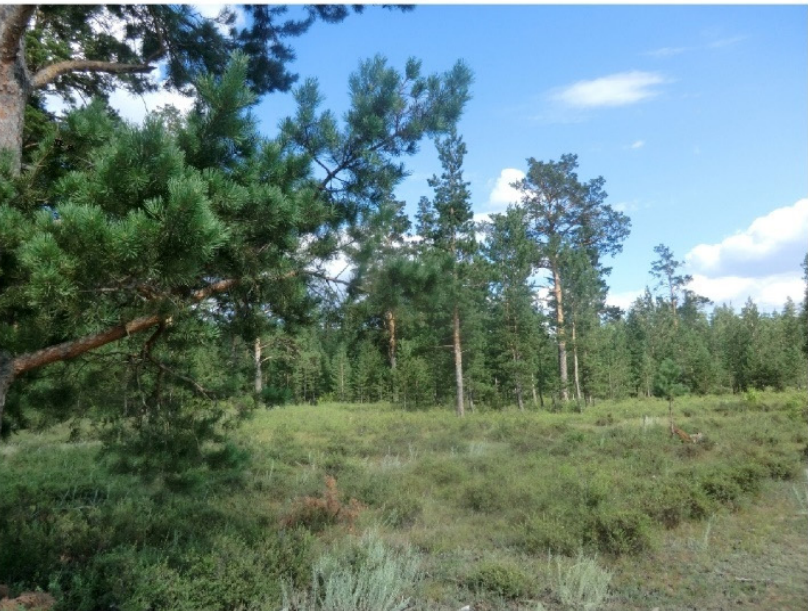

D

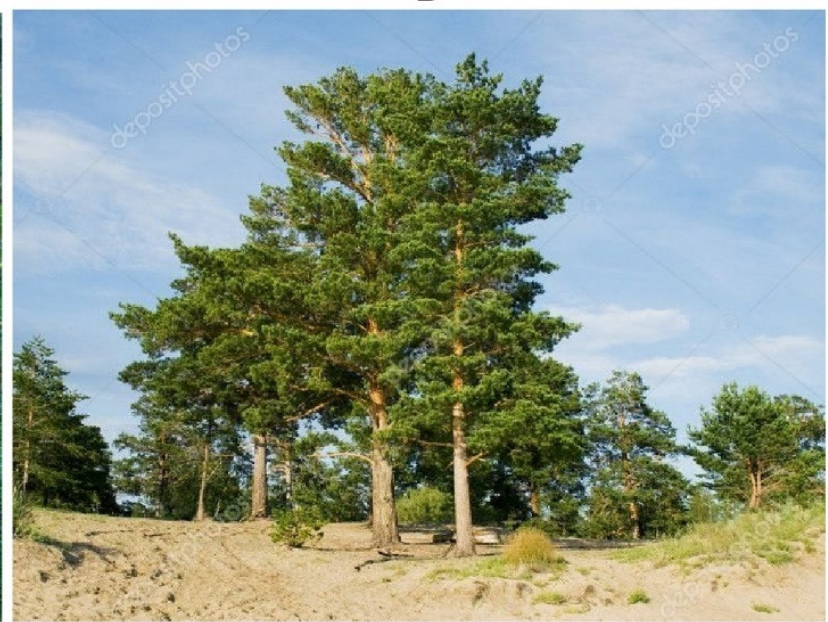

$\mathrm{F}$

Figure 4. Diversity of the pine forest cover at the Bayanaul NP (A), the Beskaragai $(\mathbf{B}, \mathbf{C})$ and the Chaldai (D-F) NR sites in respect to geomorphic setting. At both sites, the relief predetermines the particular parkland pine forest type showing the tree stands' density increase, the pine forest regeneration enhance and an overall positive forest vitality trend as a function of rising annual precipitation and ground-water availability. (A) Mountain forest (Bayanaul NP); (B) dry forest hill (TP 1); (C) upland plateau forest (TP 3); (D) semi-arid plain forest (TP 5); (E) semi-humid flat plain forest (TP 3); (F) sandy plain forest on sandy dunes above the Irtysh River floodplain. Photographs by the authors. 
The pine phytocenosis consists of three arboreal layers dominated by Scotch pine (Pinus sylvestris L.), aspen (Populus tremula, L.) and snow spiraea (Spiraea crenata L.), respectively. The average regeneration of young pine growth is $2112 \mathrm{pcs} / \mathrm{ha}$; young seedlings $800 \mathrm{pcs} / \mathrm{ha}$. The Chaldai vegetation communities are represented by the steppe fescuegrass associations (Festuca pseudovina-Koeleria glauca-Medicago falcata). The grass cover amounts to ca. $85 \%$ of the vegetated area with the average height of the herbaceous plants being $55 \mathrm{~cm}$. The phenological grassland state is represented by phases from flowering to fruiting. The plain bottom occupies a large part of the uniformly forested space with the absence of dry forests of the hilly locations as well as more humid wetland forests.

\subsection{Forest Habitat Species Composition}

The geo-botanical study of the particular plant communities included a detailed analysis of the pine phytocoenosis. The dominant plant elements were used as the main indicators reflecting the forest floristic structure and the species composition along with the pinetum (the community of pine trees) description and characteristics of forest stands according to the growth class, crown closure and density, number of regenerations, the canopy structure and the arboreal taxonomy. The pinetums of the Beskaragai ribbon-like pine forest (Site 1-Beskaragai, $6 \mathrm{TP}$ ) and the Chaldai ribbon-like pine forest (Site 2-Chaldai, $5 \mathrm{TP})$ were documented in detail. The test plots were established for the pine phytoceonosis growing in pristine natural habitats with a minor influence of anthropogenic factors (at a distance of $>25 \mathrm{~km}$ from the rural settlement communities).

The forest pinetums characteristic of the studied places are summarized in Table 2. The Beskaragai forest average crowns closure was 0.5 , growth class III-V, the total number of trees (minimum density of tree plantations) 183-440 t/ha. The vitality of trees, on average, on a five-point scale was 3 points. The Chaldai forest average crowns closure was 0.8 , growth class III, total biomass 596-1400 $\mathrm{t} / \mathrm{ha}$. The vitality of trees, on average, was 3.4 points. The layering and pine forest species composition (Table 3 ) reflect the natural factors on the structure of the forest plant communities. The increased proportion of broadleaved species in the composition of the forest stands has a positive effect on the stability of the artificial arboreal plantations.

Table 2. Characteristics of pinetum of the Beskaragai and Chaldai Nature Reserves' Forests.

\begin{tabular}{|c|c|c|c|c|c|c|c|c|c|}
\hline Test Plot & $\begin{array}{c}\text { Average } \\
\text { Age } \\
\text { (year) }\end{array}$ & $\begin{array}{c}\text { Average } \\
\text { Height (m) }\end{array}$ & $\begin{array}{c}\text { Average } \\
\text { Trunk } \\
\text { Diameter } \\
\text { (At } 1.3 \mathrm{~m})\end{array}$ & $\begin{array}{c}\text { Basal Area } \\
\left(\mathrm{m}^{2} / \mathrm{ha}\right)\end{array}$ & $\begin{array}{c}\text { Forest } \\
\text { Density } \\
\text { (pcs/ha } \times \\
1000)\end{array}$ & $\begin{array}{l}\text { Crown } \\
\text { Closure }\end{array}$ & $\begin{array}{l}\text { Density } \\
\text { tree/ha }\end{array}$ & Bonitet & $\begin{array}{l}\text { Growth } \\
\text { Cond's } \\
\text { (pts 1-5) }\end{array}$ \\
\hline \multicolumn{10}{|c|}{ Site 1-Beskaragai } \\
\hline $\mathrm{TP} 1$ & 59.0 & 10.79 & 5 & 0.86 & 0.03 & 0.3 & 440 & III & 2 \\
\hline TP 2 & 60.6 & 14.28 & 8 & 1.22 & 0.04 & 0.3 & 243 & IV & 2 \\
\hline TP 3 & 71.0 & 17.30 & 26 & 13.37 & 0.4 & 0.6 & 252 & III & 4 \\
\hline $\mathrm{TP} 4$ & 80.46 & 16.40 & 35 & 26.44 & 0.8 & 0.6 & 275 & III & 3 \\
\hline TP 5 & 69.85 & 21.25 & 32 & 19.29 & 0.5 & 0.6 & 240 & II & 4 \\
\hline TP 6 & 94.0 & 19.20 & 33 & 15.64 & 0.4 & 0.6 & 183 & III & 3 \\
\hline Av. & $72.4 \pm 13.1$ & $16.7 \pm 3.7$ & $23.1 \pm 13.3$ & $\begin{array}{c}12.80 \pm \\
10.1\end{array}$ & 0.4 & 0.5 & $272 \pm 80$ & & 3 \\
\hline \multicolumn{10}{|c|}{ Site 2-Chaldai } \\
\hline $\mathrm{TP} 1$ & 41 & 11.4 & 18 & 35.6 & 1.3 & 0.7 & 1400 & III & 3 \\
\hline TP 2 & 106 & 16.25 & 26 & 79.59 & 2.5 & 0.8 & 1500 & III & 4 \\
\hline TP 3 & 44.57 & 9.19 & 17 & 13.52 & 0.6 & 0.8 & 596 & II & 4 \\
\hline $\mathrm{TP} 4$ & 58.78 & 19.55 & 26 & 68.98 & 2 & 0.7 & 1300 & III & 3 \\
\hline TP 5 & 49.33 & 15.5 & 20 & 22.73 & 0.7 & 0.8 & 724 & III & 3 \\
\hline Av. & $59.9 \pm 26.6$ & $14.4 \pm 4.1$ & $21.4 \pm 4.3$ & $44.1 \pm 28.9$ & 1.42 & 0.76 & 1104 & & 3.4 \\
\hline
\end{tabular}


Table 3. Layered structure and species composition of forest stands (PS-Pinus sylvestris, PT-Populus tremula, BP-Betula pendula).

\begin{tabular}{|c|c|c|c|c|c|c|c|}
\hline No & $\begin{array}{c}\text { Species } \\
\text { Composition }\end{array}$ & $\begin{array}{l}\text { Canopy } \\
\text { Structure }\end{array}$ & $\begin{array}{l}\text { Dominant } \\
\text { Species }\end{array}$ & No & $\begin{array}{c}\text { Species } \\
\text { Composition }\end{array}$ & $\begin{array}{c}\text { Canopy } \\
\text { Structure }\end{array}$ & $\begin{array}{l}\text { Dominant } \\
\text { Species }\end{array}$ \\
\hline \multicolumn{4}{|c|}{ Site1-Beskaragai } & \multicolumn{4}{|c|}{ Site2-Chaldai } \\
\hline TP 1 & 10 PS & 1 & Pinus sylvestris L. & TP 1 & 10 PS & 1 & Pinus sylvestris L. \\
\hline TP 2 & $10 \mathrm{PS}$ & 1 & Pinus sylvestris L. & TP 2 & $10 \mathrm{PS}+\mathrm{PT}$ & 3 & $\begin{array}{l}\text { Pinus sylvestris L., } \\
\text { Populus tremula, L., } \\
\text { Rosa laxa Retz }\end{array}$ \\
\hline TP 3 & 8 PS 2 PT & 2 & $\begin{array}{l}\text { Pinus sylvestris L., } \\
\text { Populus tremula L. }\end{array}$ & TP 3 & 9 PS 1 PT & 3 & $\begin{array}{l}\text { Pinus sylvestris L., } \\
\text { Populus tremula L., } \\
\text { Spiraea crenata L. }\end{array}$ \\
\hline TP 4 & $10 \mathrm{PS}$ & 1 & Pinus sylvestris L. & $\mathrm{TP} 4$ & $10 \mathrm{PS}$ & 1 & Pinus sylvestris L. \\
\hline TP 5 & 9 PS 1 PT & 2 & $\begin{array}{l}\text { Pinus sylvestris L. } \\
\text { (Populus tremula L.) }\end{array}$ & TP 5 & $10 \mathrm{PS}$ & 2 & $\begin{array}{l}\text { Pinus sylvestris L. } \\
\text { Spiraea crenata L., } \\
\text { Ribesnigrum L. }\end{array}$ \\
\hline TP 6 & 10 PS & 1 & Pinus sylvestris L. & & & & \\
\hline
\end{tabular}

The prevailing composition formula for the forest stands in the Beskaragai and Chaldai ribbon-like pine forests is 10 . The indexes PS $+\mathrm{PT}$ document the dominance of the common pine (Pinus sylvestris L.) with a rather minor presence $(<1 \%)$ of aspen (Populus tremula L.). The layering of the studied plant communities is represented by a range of variations. Whereas in the Beskaragai forest, single-layered stands prevail, the Chaldai forest shows the three-layered stands of common pine, aspen and snow spiraea (Spiraea crenata L.). Measurable data of the plantations and the biological and physical characteristics of the forest structure allow for their quantitative and qualitative assessment, including the state of the pine forests.

The average age for the Beskaragai and Chaldai ribbon-like pine forests is 72 years (max. 94 years) and 59 years (max. 106 years), respectively. The corresponding average pine tree height at the Beskaragai is $16.69 \mathrm{~m}$ with a trunk diameter of $23.16 \mathrm{~cm}$; at the Chaldai site it is $14.3 \mathrm{~m}$ with a trunk diameter of $21.4 \mathrm{~cm}$. At both locations, the average height and average diameter gradually increase with the higher tree age. However, at the sites of different growing conditions, an unequal average height and diameter of the trees' trunk of the same age trees were observed. At the forestage of ca. 60 years, the stand in the Beskaragai forest has a height of $14.28 \mathrm{~m}$, and $19.55 \mathrm{~m}$ in the Chaldai pine forest. In the Chaldai forests and the forests in the Irtysh Lowland area, tree density is higher because of the better natural conditions and the biomass productivity compared to the dry hilly landscape of the Beskaragai NR area.

\subsection{Ecological Type of Vegetation}

In the context of the on-site studies, the soil moisture balance together with the total amount of mean annual precipitation (MAP) proved to be the key factors predetermining the ecological structure of the arboreal biotopes in the Beskaragai and Chaldai pine forest reserves (Figure 5A). In the Beskaragai pine forests, both on the hilly and plain settings, xeromesophytes and xerophytes predominate, indicating overall arid conditions (Figure 5B). The Chaldai pine forests show a higher number of xero-mesophytes and mesophytes, as well as the presence of hydro-mesophytes due to the better wetted soils with a moderate year-round air humidity (Figure 5C).

The results show that the particular ecological conditions at each of the investigated sites predispose the growth status and the taxonomic variety of flowering and non-flowering plants. At all the investigated sites, the xero-mesophytes predominate, with the highest representation in the Beskaragai hilly upland pine forest due to the progressing regional aridity and a tendency to landscape desertification. 


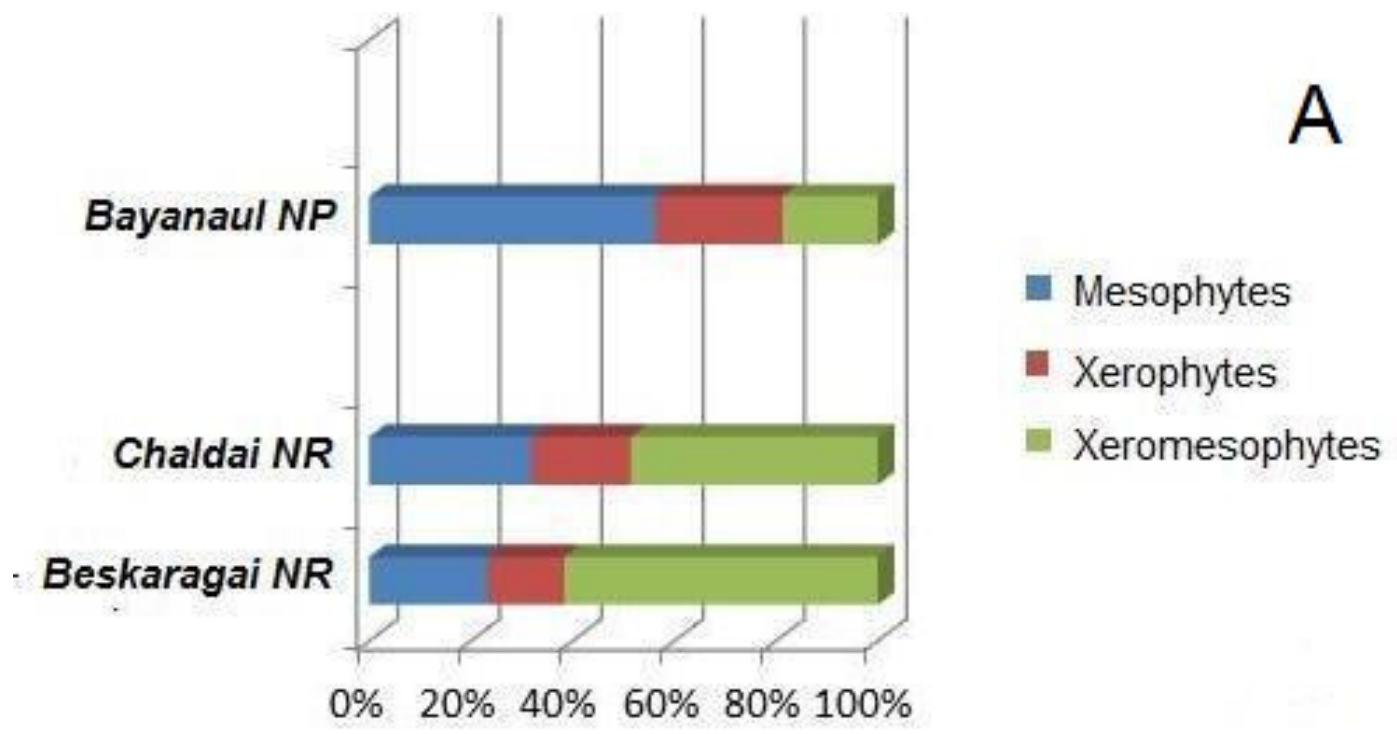

Beskaragai NR B
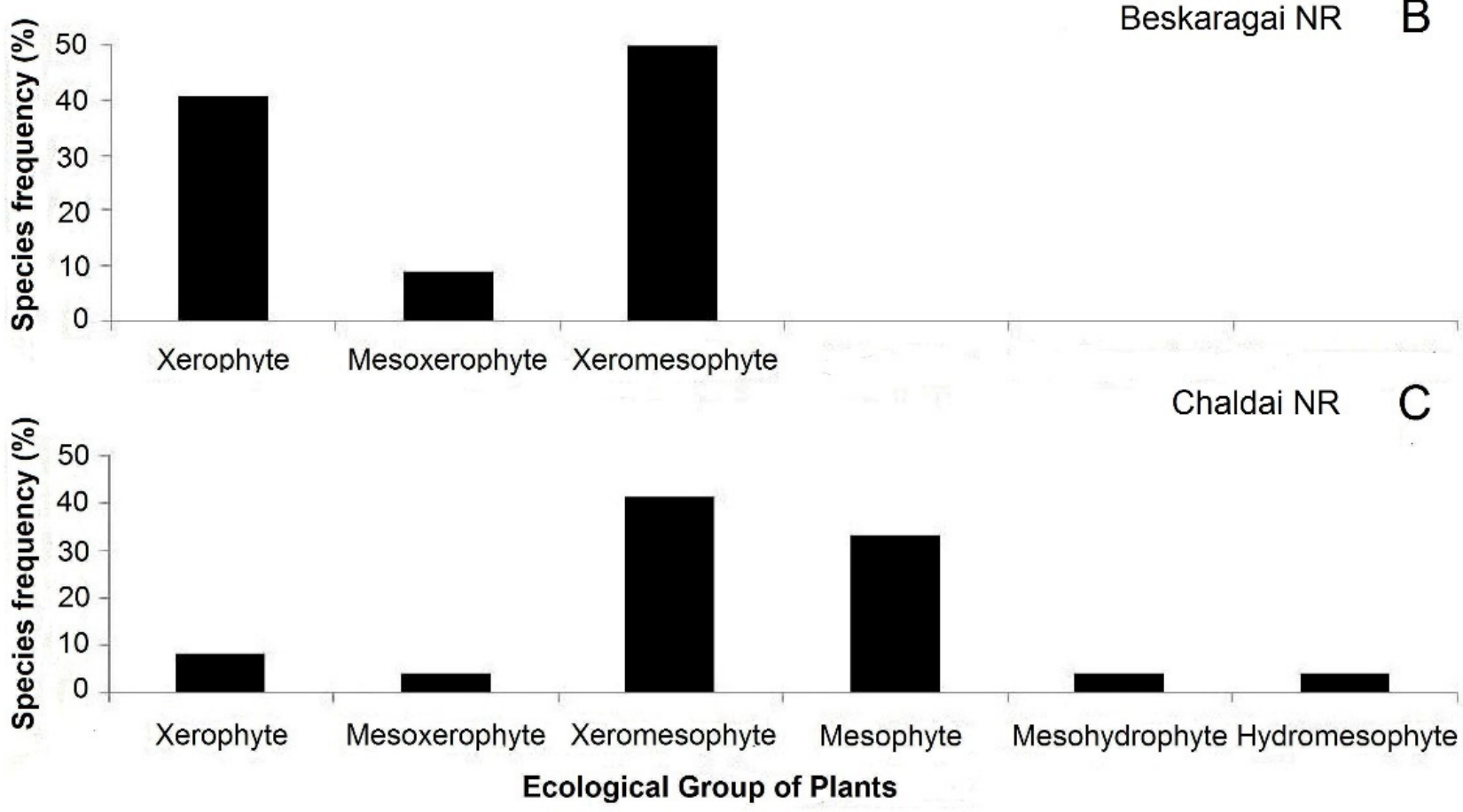

Figure 5. Ecological groups of plants of the broader area within the Bayanaul Nature Park, the Chaldai and Beskaragai Nature Reserves (A); and the Beskaragai upland pine forest (B) and the Chaldai plain pine forest $(\mathbf{C})$.

\subsection{Pine Phytocenosis Floristic Composition}

The floristic composition of the pine forests phytocenosis in the Beskaragai and Chaldai nature reserves' sites mirrors the natural factors affecting the plant communities of the NE Kazakhstan pine forests with some significant differences recorded at the investigated loci in terms of natural and invasive plant species (Figures 6 and 7). 

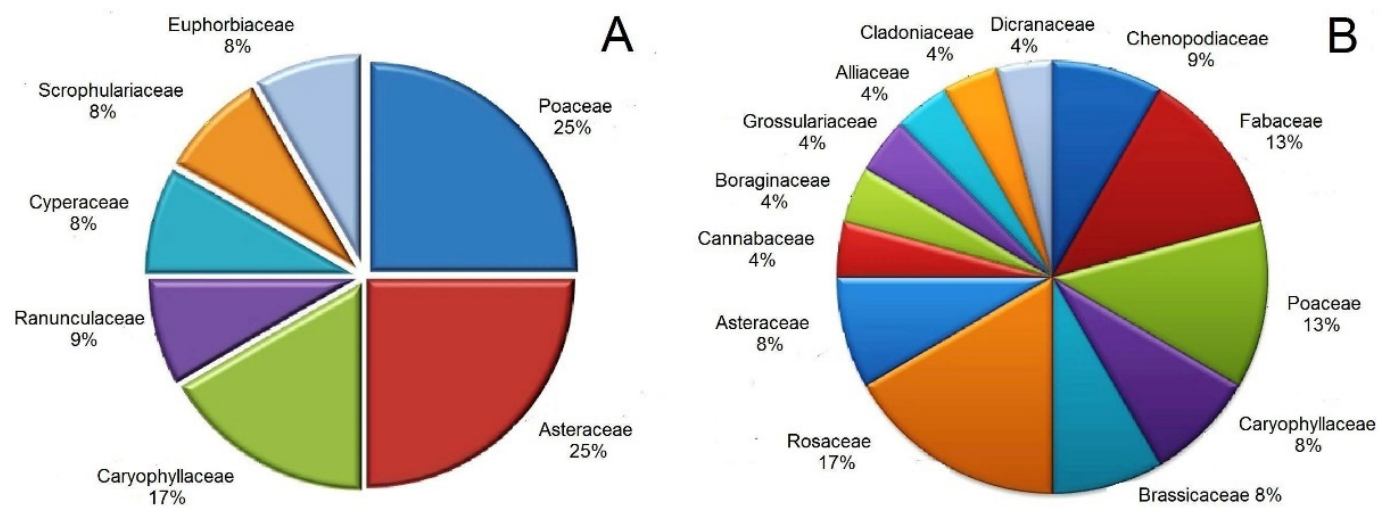

Figure 6. Plant species structure of the Beskaragai upland (A) and the Chaldai plain (B) pine forests.
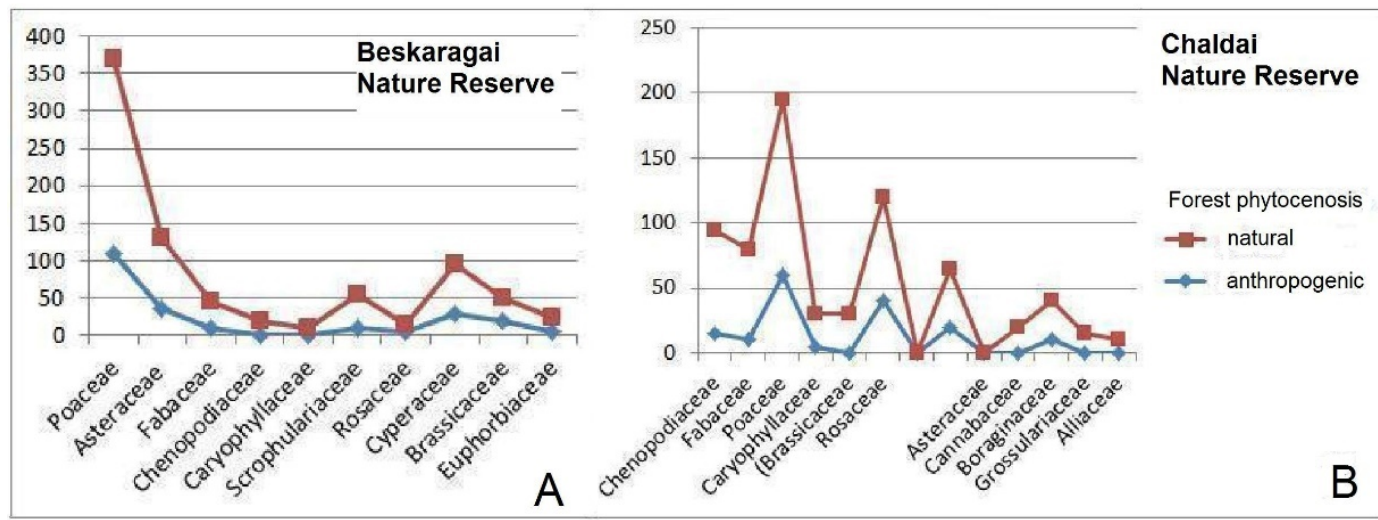

Figure 7. Pine forest undergrowth phytocenosis of the natural and invasive anthropogenic plant species in the Beskaragai (A) and Chaldai (B) nature reserves.

The Beskaragai forests are characterized by the predominance of grasses and sedges. Based on the particular geomorphic relief, two types of the arboreal cover (i.e., the semidry upland forests and more humid plain forests) were identified, with the increased species diversity in the latter. The undergrowth cover of the upland pine forest largely encompasses species of 7 plant families-Poaceae (25\%), Asteraceae (25\%) and Caryophyllaceae $(17 \%)$, with the remaining taxa of Ranunculaceae, Cyperaceae, Scrophulariaceae, Euphorbiaceae less represented (14\% in total) (Figure 6A). The richer spectrum found in the plain forests accounts 24 species of 14 families-Poaceae (13.8\%), Asteraceae (13.8\%), and Equisetaceae, Brassicaceae, Caryophyllaceae, Scrophulariaceae (altogether 27.6\%). For the herbaceous plants, the following characteristics were revealed: $60 \%$ projective cover degree, the average height $30 \mathrm{~cm}$, a two-layered (grasses-sedges) community structure. The phenological state of herbaceous plants is in the phase of fruit and seed ripening.

In the Chaldai ribbon-like pine forest, 24 species of 13 families were identified. Rosaceae $(16.6 \%)$, Fabaceae (12.5\%), Poaceae (12.5\%), Chenopodiaceae, Caryophyllaceae, Brassicaceae, Asteraceae (33.2\% in total) are dominant (Figure 6B). For the herbaceous plants, the projective grass cover was $85 \%$, and the average height of plants was $55 \mathrm{~cm}$. The growth indicators exceeding those at the Beskaragai site point to more favorable environmental conditions.

\subsection{Natural Regeneration Dynamics of Pine Forests}

The dynamics of the natural regeneration of the Pri-Irtysh pine forests points to a certain restoration of forest ecosystems after anthropogenic damage (long-term logging, burning). The availability and quality of young seedlings and the young growth can be used to judge the intensity and restoration potential of the regional forest resources naturally, with several regenerations/successions identified promoting the pine forests' persistence. At the Beskaragai site, all the relief-determined forest types (from the high hills 
to the plains) show a certain natural vitality. Due to the site-specific growing conditions, there are variations in the number of young seedlings and the young pine forest growth (Figure 8A).

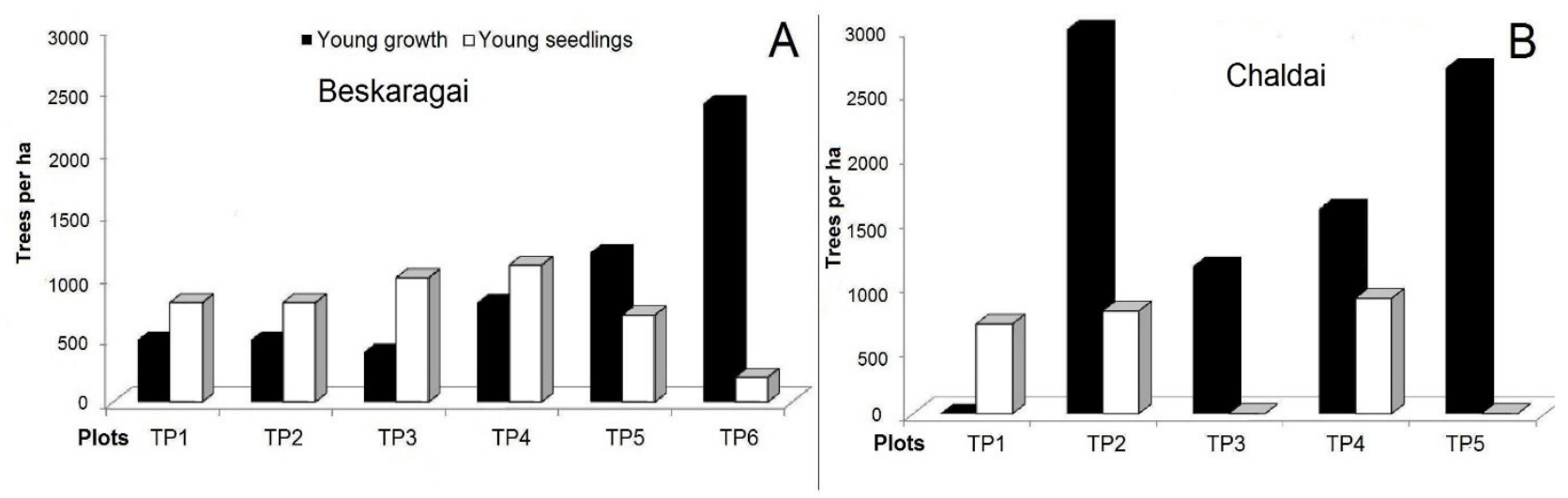

Figure 8. Restoration of pinetums of the Beskaragai (A) and the Chaldai (B) pine forests.

In the Beskaragai ribbon-like pine forest, the young growth restoration index is 966 units/ha and 766 units/ha of young seedlings. The young growth shows the highest concentrations in the plain forests due to the moisture-retaining gley soils and shallower groundwater. The number of young seedlings is, on the contrary, smaller, because of the high cover of herbaceous plants and the presence of aspen thickets impeding the spread of the pine seedlings. In the semi-dry pine forests, the intensity of the young pine growth is smallest due to dry, loose sandy permeable soils incapable of retaining ground moisture. The young pines are grouped closer to the seed trees, mainly on the western rain-receiving hill slopes and uplands.

The Chaldai pine forest regeneration process (Figure 8B) shows a significantly higher density of young pine seedlings and growth in comparison with the Beskaragai pine forest amounting to 2.112 units/ha of young growth and 800 units/ha of young seedlings. This indicates a rather positive restoration dynamic of the forest ecosystems. At more favorable growing conditions, the amount of self-sowing reaches 1.700 pcs per ha [58]. At the Chaldai forest's TP3 and TP5 transect loci, the absence of young seedlings reflects the high projective cover rate of the herbaceous plants and spiraea young growth preventing the natural arboreal cover restoration along with forest-adverse anthropogenic actions (cattle grazing). Spring season climatic conditions (ground humidity and temperature) are seen as the primary factors determining the variations in seedlings' growth and the pine tree biomass increase [59].

\section{Discussion}

\subsection{Pine Forest Distribution and Dynamics}

The investigations in the Irtysh region of NE Kazakhstan based on the geo-environmental profiling revealed distinctly different types and growth dynamics of the local pine forest cover reflecting the presently changing climate conditions and the regional hydrology regime.

1. The varied forest vitality displays specific natural conditions. The more ecologically fragile semi-arid pine cover on the sandy hills and the granitic bedrock uplands (200-270 $\mathrm{m}$ asl) transgressing into the lower elevation plain and lowland plain pine forests (120-220 $\mathrm{m}$ asl.) are distributed in the arid and geomorphologically more profiled Beskaragai area (Figure 4A-C). The plain pine forests (157-220 m asl) are characteristic of the lowland Chaldai area (Figure 4D-F). Despite having about the same annual precipitation rate $(262 / 270 \mathrm{~mm})$, the latter region shows a better vitality of the arboreal growth as well as the richer phytoceonosis due to the better hydrogeology conditions with balanced groundwater availability and bedrock permeability. 
2. The average age of the Beskaragai nature reserve forest stands is 72 years, with an average height of $16.7 \mathrm{~m}$, and a trunk diameter of $23 \mathrm{~cm}$. In the Chaldai NR, the average forest age is 59 years, height $14.3 \mathrm{~m}$, and a trunk diameter of $21.4 \mathrm{~cm}$. The pinetums in the Beskaragai and Chaldai forests have average tree crown closures of 0.5 and 0.8 , respectively. Single- and two-layered forest stands prevail at both locations. The projective herbaceous cover amounts to $60 \%-85 \%$, the average height of plants is $30-55 \mathrm{~cm}$. Two-layered plant communities are common.

3. The floristic composition differs markedly between the two areas. The Beskargai forests have a poorer phytocenosis structure with a predominance of grass-sedge (Stipa joannis Cel., Carex supine Willd.) associations. The more productive Chaldai forests show successful vegetation restoration and a richer floristic composition dominated by the forbs-fescue communities (Festuca pseudovina Hack., Koeleria glauca, Medicago faclata L.).

4. The ecological types of the local herbaceous cover encompass various combinations. For the Beskaragai high hill pine forest and plain pine forest, the xero-mesophytes and xerophytes prevail, indicating arid conditions for the conifers' growth. The Chaldai pine forest shows greater numbers of the xero-mesophytes and mesophytes, as well as the presence of hydro-mesophytes due to the presence of wetter soils and the moderate microclimate humidity.

5. The restoration dynamics in the Beskaragai area display a gradual increase in the common pine (Pinus sylvestris L.) seedlings on the semi-arid high-hill positions as well as on the lowlands, and a decrease in pine seedlings on the open plains due to the dense grass cover. In the Beskaragai NR, the restoration (seedlings) rate is 766-966 $\mathrm{pcs} / \mathrm{ha}$. In the Chaldai NR, the conditions for the natural pine forest succession are more favorable with the significantly more vital growth of young trees with density of 1150-3000 pcs/ha.

6. A low and the average degree of the phytocenosis degradation is documented at the Chaldai forest and the Beskaragai forest, respectively. The semi-arid forests at Beskaragai found on the topographic elevations have the lowest revitalization capability and a higher ecological vulnerability due to the groundwater deficiency, rocky bedrock and stronger winds, depriving the surface cover of ground moisture in combination with increased insolation.

\subsection{Territorial Pine Forest Sustainability}

The assessment of the vitality of the predominantly mixed pine-birch forest ecosystems in NE Kazakhstan displays significant variations in the floristic composition, geo-botany as well as differences in the state and degree of degradation of the pine phytocenoses. Our research revealed that the average degree of degradation is well expressed in the Beskaragai NR, namely, the semi-dry pine forests in which the associated plant community spectrum is small. Accordingly, the Beskaragai site is characterized by a poorer floristic composition with a predominance of xerophytes on regosolic sandy soils with a low projective vegetation cover and a limited arboreal cover restoration capability. In contrast, the Chaldai NR forests show a reduced degree of the conifers' degradation and a solid natural restoration potential. The prevailing floristic composition of xero-mesophytes and hydromesophytes reflect more favorable environmental conditions within the semi-arid steppe climate-geographic subzone (Table 4).

By analyzing the environmental impact on the Pri-Irtysh pine forest complexes, three degrees of degradation were identified. Minor degradation preserves the original soil and vegetation cover in a natural or restoration stage. The average degree of degradation is not accompanied by noticeable changes in the ecosystem despite a soil and vegetation cover distortion, with persisting preservation of the dominant plant species. A strong degree of degradation (of soil and vegetation) is encountered only locally and is confined to the anthropogenic factors. Despite these adverse ecological aspects, the unique feature of the investigated 
pine forests lies in the rich, yet fragile biodiversity of the enclosing parkland habitats defined by the site-specific biogeomorphic parameters (relief, soil, hydrology, phytocenoses).

Table 4. Summary characteristics of the Pri-Irtysh ribbon-like pine forests' growth dynamics.

\begin{tabular}{|c|c|c|}
\hline Area (Nature Reserve) & Beskaragai & Chaldai \\
\hline Altitude & $120-270 \mathrm{~m}$ asl & $157-220 \mathrm{~m}$ asl \\
\hline Annual precipitation (MAP) & $262 \mathrm{~mm}$ & $270 \mathrm{~mm}$ \\
\hline Forest type & $\begin{array}{l}\text { Semi-arid highland forests } \\
\text { Plain and lowland pine forests }\end{array}$ & Plain pine forests \\
\hline Geomorphic setting & Sandy hills and granite bedrock uplands & $\begin{array}{l}\text { The Ob River Plateau } \\
\text { (the Kulunda Plain) }\end{array}$ \\
\hline Average age of forest stands & 72 years & 59 years \\
\hline Average tree height & $16.7 \mathrm{~m}$ & $14.3 \mathrm{~m}$ \\
\hline Trunk diameter & $23 \mathrm{~cm}$ & $21.4 \mathrm{~cm}$ \\
\hline Crown cover & 0.5 & 0.8 \\
\hline Plant community structure & \multicolumn{2}{|c|}{$\begin{array}{l}\text { Single- and two-layered forest stands. Herbaceous plants' projective cover } 60 \%-85 \% \text {, } \\
\text { the herbaceous plants average height } 30-55 \mathrm{~cm} \text {. Two-layered plant communities. }\end{array}$} \\
\hline Floristic composition & $\begin{array}{c}\text { A poorer phytocenosis structure, } \\
\text { predominance of the grass-sedge } \\
\text { communities (Stipa joannis Cel., Carex } \\
\text { supine Willd.). }\end{array}$ & $\begin{array}{c}\text { A richer floristic composition dominated } \\
\text { by the forbs-fescue communities (Festuca } \\
\text { pseudovina Hack., Koeleria glauca DC., } \\
\text { Medicago faclata L.). }\end{array}$ \\
\hline Ecological types of the local plants & $\begin{array}{l}\text { Xero-mesophytes and xerophytes } \\
\text { indicative of arid conditions }\end{array}$ & $\begin{array}{l}\text { Xero-mesophytes and mesophytes, } \\
\text { hydro-mesophytes due to wetter soils } \\
\text { with moderate humidity }\end{array}$ \\
\hline Restoration (seedlings) & 766-966 pcs/ha & $900-3000 \mathrm{pcs} / \mathrm{ha}$ \\
\hline $\begin{array}{c}\text { Degree of the pine tree phytocenosis } \\
\text { degradation }\end{array}$ & Average & Low \\
\hline Forest dynamics & $\begin{array}{l}\text { Slow vegetation cover restoration; higher } \\
\text { environmental fragility }\end{array}$ & $\begin{array}{l}\text { Higher vegetation restoration with } \\
\text { productive forest stands }\end{array}$ \\
\hline
\end{tabular}

The investigations confirmed the resistance of the Kazakhstan ribbon-line pine forests to modern natural disruptions within certain limits and the local bio-geographic conditions. At the same time, the results provided evidence of differences in predisposition for revitalization [60], with the Chaldai forests characterized by a higher regeneration potential and ecosystem stability/sustainability. Degradation and restoration of the regional arboreal cover thus occur at different levels of the pine forest ecosystem in reaction to the changing environmental situation. At the plant community level, this may lead to impoverishment or even replacement of the pristine phytocenoses and a biodiversity loss as a result of excessive landscape disruptions $[61,62]$. At the level of forest types, these processes cause a retreat of the native forests at some monitored loci (the Beskaragai hills), contrasting with an expansion of the naturally forested area elsewhere (the Chaldai plains).

\subsection{Environmental Risks to Forest Cover}

The applied criteria of environmental change linked to forest degradation relate to the main causes of forest decline, both natural and anthropogenic [63,64]. The pine forests of the steppe zone of northern and NE Kazakhstan show various succession stages subjected to multiple environmental risks. The current biotic shifts due to aridification are seen in the decrease in the trees' status vitality, the reduction of their natural restoration capability, the loss of the pristine plant diversity with increasing proportions of xerophytes in the steppe forests plant communities. The forests on the sandy soils undergo natural disruptions in the form of fires, high summer temperatures, severe winters with a low snow cover and 
insufficient ground moisture, altogether contributing to landscape desertification. Apart from natural fires, human-induced forest burning, intensified pastoralism in the rural settlements' environs adversely affecting especially the young forest growth, a major negative effect on the long-term health and the revitalization capacity of the NE Kazakhstan pine forests, they may have radioactive contamination resulting from the Semipalatinsk nuclear testing site causing presumably about a $50 \%$ reduction of the normal wood mass increment rate and the overall poorer state of the arboreal cover over the broader territory [65]. Although the studied Beskaragai and Chaldai pine forest nature reserves are state-protected, they are very susceptible to modern anthropogenic damage. The highland forests are, furthermore, negatively affected by increasing recreational activities. A vital management program of environmental protection and a forest revitalization strategy should be implemented by taking into account the extreme continental settings of the intra-zonal steppe forests in the Pri-Irtysh region.

Overall, North Kazakhstan's forests suffer due to the progressing desertification in response to the ongoing territorial warming $[66,67]$. The process of the northern/southern steppe expansion/retreat during the warm/cold climate stages, respectively, is well documented in the Irtysh Basin during the Holocene [8]. Activated sands experience increasing transfer into the present grassland and parkland-steppe belt accompanied by a northern retreat of the coniferous taiga. The present shortening of forest resources in SW Siberia and Northern Kazakhstan is largely due to modern industrial activities [68]. Local reduction of the pine forest cover by the increased fire frequency in Siberia leads to an extension of steppes [9]. In turn, the ribbon-like pine forest fires contribute to their rapid regeneration and ameliorating forest-growth conditions $[69,70]$.

\subsection{Climate Change Feedback}

Cold dry winters and semi-humid warm summers (mean temp. January $-16.7^{\circ} \mathrm{C}$, July $+21.3^{\circ} \mathrm{C}$ ) characterize the pronounced continentality of the area (Figure $9 \mathrm{~A}$ ). The longterm trend of the MAAT increase in NE Kazakhstan is less prominent than in the adjoining mountain and lowland areas of Siberia [71,72], corresponding to just about $+0.4{ }^{\circ} \mathrm{C}$ rise over the period between 1990-2020 with the documented annual thermal maximum in 2020 (Figure 9B). Yet, this constant change promotes the apparent expansion of steppes at the expense of birch-pine forests. This trend is less noticeable in the better-watered Irtysh lowlands, particularly due to the late spring and summer rainfalls (Figure 9C). Mean annual precipitation records show about 8-10 year MAP volume cyclicity over the past thirty years, with peaks in 1992, 2000, 2009 and 2018 (Figure 9D). The colder years manifest increased MAP volumes, whereas the drier years correspond to hot late spring-summer seasons. This atmospheric evidence corroborates the conclusions of dendrology studies in the Beskaragai and Chaldai NR showing increased pine growth (biomass) intensity in the corresponding precipitation-rich years.

A positive forest-growth trend has been observed on the adjoining Altai Plains and in the Gorno Altai mountains with a significant altitudinal ribbon-forest expansion [37], as the joint effect of increased annual precipitation and warming [73,74]. An analogous landscape cover evolution with the thriving Scotch pine forests over the Steppe Altai, similar to today, was recorded during the mid-Holocene optimum [75]. The emerging climate-bio-geographic evidence shows regional disparities between the current climate variations and the forest growth dynamics in dependence to local natural conditions. This is well-seen in the investigated area.

Based on the present study, the more rainfall-watered and air-moistened locations in the low-lying depressions between the Pri-Irtysh hills provide the most favorable conditions for sustainment and natural reproduction of the pristine arboreal communities in northern Kazakhstan. The research results provide new insights on the pine forest dynamics in the parkland-steppes of central Eurasia, with practical applications to the environmental risk assessment, nature protection, forestry, agriculture and regional sustainable development. 

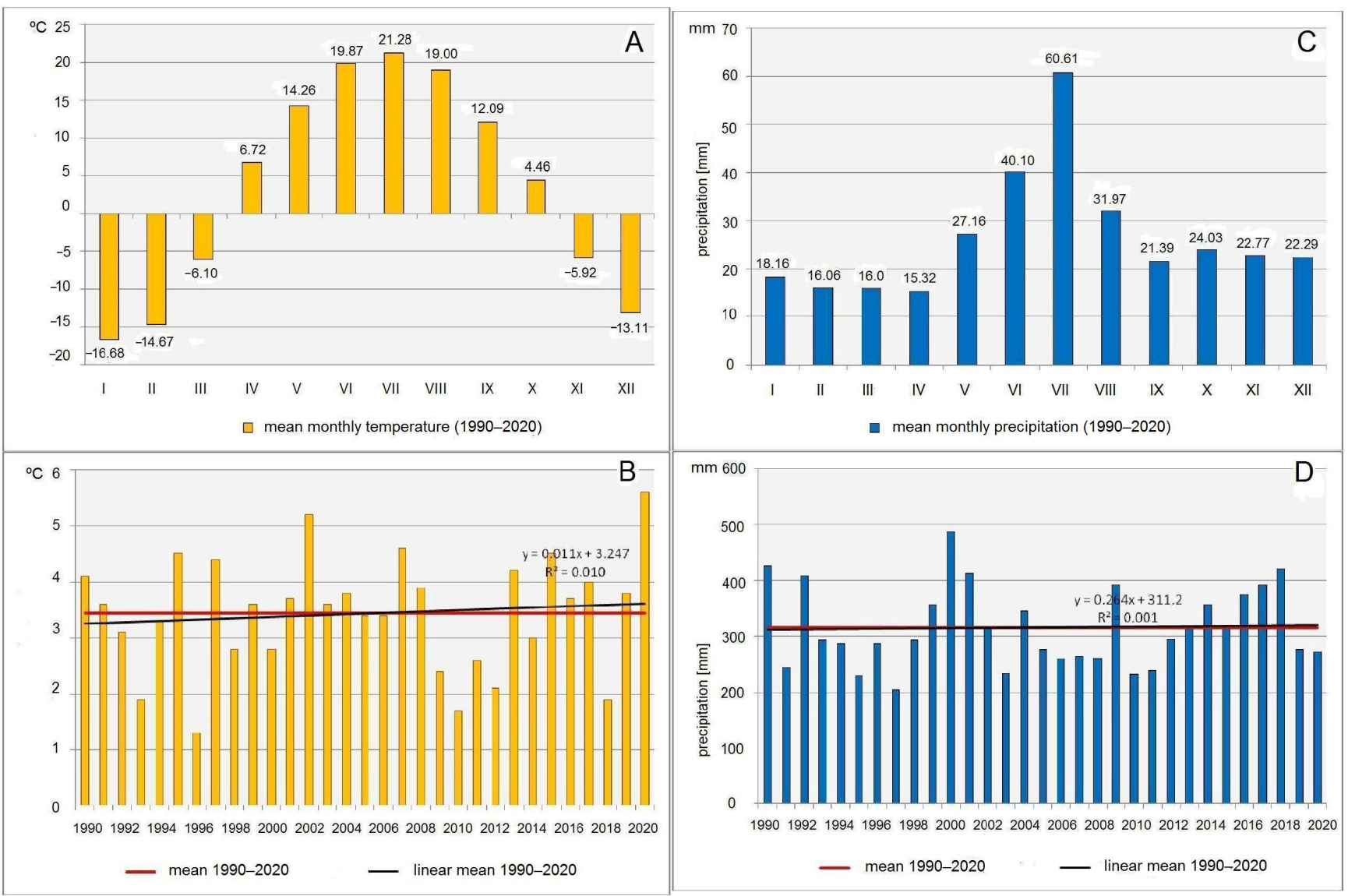

Figure 9. Mean air temperature and precipitation records for NE Kazakhstan for the 1990-2020 period. (A) Monthly mean temperature; (B) annual mean temperature with a trend-line and regression equation of the MAAT anomalies showing just a slightly rising regional temperature during the last ten years; (C) monthly mean precipitation; (D) annual precipitation record with a minor long-term precipitation increase over the past decades (analysis of the raw meteorological data; the Pavlodar Meteorological Station).

\section{Conclusions}

The Pri-Irtysh ribbon-line pine forests are the key natural indicators of regional environmental stability and ecosystem functioning. The complex environmental and geo-botanical investigations performed in the two nature reserves of NE Kazakhstan, representing a transitional zone of Central Asia's semi-deserts most susceptible to climate change, steppes and parklands, disclosed marked variations between the upland and the lowland forest ecosystems. The forest growth dynamics display a differential intensity of the pine seedling successions and stability of the arboreal cover with the lowland ribbon-like pine forests showing a better vitality, natural restoration capability as well as greater floristic diversity of the forests phytocenosis diagnostic of the pristine parkland habitats. The variations in the forest cover distribution patterns, the sylvan structure and the tree growth characteristics of the arboreal communities reflect the particular geomorphic settings and the current atmospheric conditions predetermining the pine stands' status. Following the present regional aridification trend, the rocky topographic elevations, along with the extensive highlands and uplands of northern Kazakhstan will experience a major pine forest decline and a forest retreat into more isolated and primarily groundwater-fed locations in the riverine lowlands. The study findings have direct bearings for the national forestry planning in the central Eurasian parkland areas, depleted of the natural pine forests by modern anthropogenic activities and/or exposed to the acute environmental transformations due to current climate change. 
Author Contributions: Conceptualization, S.Z., J.C. (Jiri Chlachula) and A.Z.-F.; data collection, A.Z.-F., S.Z., J.C. (Jiri Chlachula), J.C. (Jolanta Czerniawska), G.S., N.N., A.M. and E.B.; methodology, A.Z.-F., J.C. (Jolanta Czerniawska); formal analysis, A.Z.-F., J.C. (Jolanta Czerniawska), N.M. and S.Z.; writing-draft, A.Z.-F. and J.C. (Jiri Chlachula); writing-review \& editing, J.C. (Jiri Chlachula). This study results from an independent basic and analytical research of the authors' organizations and institutions (p. 1). All authors have read and agreed to the published version of the manuscript.

Funding: The Kazakhstan Ministry of Education and Science-project Study of the influence of environmental factors on the dynamics of the state of forest ecosystems in the steppe zone of Kazakhstan (Grants no. AP05130791, 242/2019).

Institutional Review Board Statement: Not applicable.

Informed Consent Statement: Not applicable.

Data Availability Statement: Data supporting the reported results can be found at the Department of Biology, Saken Seifullin Kazakh Agrotechnical University, Nur-Sultan, and the Environmental Research Centre in Stare Mesto, Czech Republic.

Acknowledgments: The investigations in the Pri-Irtysh steppe area were supported by the Saken Seifullin Kazakh Agrotechnical University, and the Environmental Research Centre, Stare Mesto.

Conflicts of Interest: The authors declare no conflict of interest.

\section{References}

1. Karibaeva, K.; Long, C. Forests and Forestry of the Republic of Kazakhstan. Ecol. Ind. Kazakhstan 2018, 2, 20-23. (In Russian)

2. Gudochkin, M.V.; Chaban, P.S. The Forests of Kazakhstan; Academy of Sciences KazSSR: Alma-Ata, Kazakhstan, 1958. (In Russian)

3. Kashlev, A.V. Paragenetic landscape systems of steppe physiographic provinces of the Altai plain. Bull. TSPU 2011, 5, 160-163. (In Russian)

4. Zhaglovskaya, A.; Chlachula, J.; Thevs, N.; Myrzagaliyeva, A.; Aidosova, S. Natural Regeneration Potential of the Black Saxaul Shrub-Forests in Semi-Deserts of Central Asia-The Ili River Delta Area, SE Kazakhstan. Pol. J. Ecol. 2017, 3, $352-368$.

5. Gribanov, L.N. Steppe Forests of the Altai Territory and Kazakhstan; Nauka: Moscow, Russia, 1960. (In Russian)

6. Mapitov, N.B.; Zhumadina, S.M. Tree-Ring Analysis of Radial Increment of Pinus Sylvestris L. in Shalday Pine Forests in The Northeast of Kazakhstan. Res. J. Pharm. Biol. Chem. Sci. 2016, 7, 180-187.

7. Velichko, A.A. (Ed.) Evolution of Landscapes and Climates of Northern Eurasia. Late Pleistocene-Holocene; Elements of Prognosis; Issue 1, Regional Palaeogeography; Nauka: Moscow, Russia, 1993. (In Russian)

8. Zakh, V.; Ryabogina, N.; Chlachula, J. Climate and environmental dynamics of the mid-to late Holocene settlement in the Tobol-Ishim forest-steppe region, West Siberia. Quat. Int. 2010, 220, 95-101. [CrossRef]

9. Buryak, L.V.; Sukhinin, A.I.; Kalenskaya, O.P. Effects of fires in ribbon-like pine forests of southern Siberia. Contemp. Probl. Ecol. 2011, 4, 248-253. [CrossRef]

10. Samarkhanov, T.N.; Myrzagaliyeva, A.B.; Chlachula, J.; Kushnikova, L.B.; Czerniawska, J.; Nigmetzhanov, S.B. Biocenosis and environmental implications of the steppe lakes of East Kazakhstan. Sustainability 2021, 13, 5756. [CrossRef]

11. Pashkovsky, K.N. Renewal of Pine in the Pine Forests of the Irtysh River; Academy of Sciences KazSSR: Alma-Ata, Kazakhstan, 1951. (In Russian)

12. Vangnits, P.R. Ribbon-Like Pine Forests; Goslesbumizdat: Moskow, Russia, 1953. (In Russian)

13. Gribanov, L.N. The Altai Territory and Kazakhstan; Nauka: Moscow, Russia, 1954. (In Russian)

14. Gribanov, L.N. On the history of steppe forests of Western Siberia and Northern Kazakhstan. Bot. J. 1957, 4, 556-570. (In Russian)

15. Olenin, S.M. Climate-related dynamics of radial growth of pine in the ribbon forests of Kazakhstan and its forecast. In Temporal and Spatial Climate Changes and Tree Growth Rings; Olenin, S.M., Mazepa, V.S., Eds.; Part 2, Academy of Sciences: Kaunas, Lithuania, 1987; pp. 53-62.

16. Bugaev, V.A. Forestry of Pine Forests of the Altai Territory; Altai Book Publishing House: Barnaul, Russia, 1988. (In Russian)

17. Galetskaya, G.A. The Influence of Anthropogenic Factors on the Restoration of Scots Pine in the Ribbon Forests of the Altai Territory; ASU Press: Barnaul, Russia, 2007. (In Russian)

18. Jian, N. Forest productivity of the Altay and Tian-Shan Mountains in the dryland, northwestern China. For. Ecol. Manag. 2004, $202,13-22$.

19. Fu, Q.; Li, B.; Hou, Y.; Bi, X.; Zhang, X. Effects of land use and climate change on ecosystem services in Central Asia's arid regions: A case study in Altay Prefecture, China. Sci. Total Environ. 2017, 607-608, 633-646. [CrossRef]

20. Simula, M. Towards defining forest degradation: Comparative analysis of existing definitions. In Forest Resources Assessment Working Paper 154; Food and Agriculture Organization: Rome, Italy, 2009.

21. Parry, M.L.; Canziani, O.F.; Palutikof, J.P.; van der Linden, P.J.; Hanson, C.E. Contribution of Working Group II to the Fourth Assessment Report of the Intergovernmental Panel on Climate Change; Cambridge University Press: Cambridge, UK, 2007. 
22. Lambin, E.F. Monitoring forest degradation in tropical regions by remote sensing: Some methodological issues. Glob. Ecol. Biogeogr. 1999, 8, 191-198. [CrossRef]

23. Devi, U.; Behera, N. Assessment of plant diversity in response to forest degradation in a tropical dry deciduous forest of Eastern Ghats in Orissa. J. Trop. For. Sci. 2003, 15, 147-163.

24. Hartanto, H.; Prabhu, R.; Widayat, A.S.E.; Asdak, C. Factors affecting runoff and soil erosion: Plot-level soil loss monitoring for assessing sustainability of forest management. For. Ecol. Manag. 2003, 180, 361-374. [CrossRef]

25. Chazdon, R.L. Beyond deforestation: Restoring forests and ecosystem services on degraded lands. Science 2008, 320, 1458-1460. [CrossRef] [PubMed]

26. Ahrends, A.; Burgess, N.D.; Milledge, S.A.H.; Bulling, M.T.; Fisher, B.; Smart, J.C.R.; Clarke, G.P.; Mhoro, B.E.; Lewis, S.L. Predictable waves of sequential forest degradation and biodiversity loss spreading from an African city. Proc. Natl. Acad. Sci. USA 2010, 107, 14556-14561. [CrossRef] [PubMed]

27. Mapitov, N.B.; Zhumadina, S.M. Dependence of the radial growth of Scots pine (Pinus sylvestris L.) on natural environmental factors in the Chalday Tape Forest. Sci. Alm. 2015, 10-13, 409-413. (In Russian)

28. Mapitov, N.B.; Zhumadina, S.M. Dynamics of annual growth of common pine (Pinus sylvestris L.) of island burs in the northeast of the Republic of Kazakhstan due to climatic factors. Int. Acad. J. 2017, 9, 49-52. (In Russian)

29. Chlachula, J.; Zhaglovskaya, A.A. Environmental aspects of the Black Saxaul forest distribution in the cold semi-deserts of Central Asia. In Proceedings of the 17th International Multidisciplinary Scientific Geo-Conference SGEM, Sofia-Albena, Bulgaria, 29 June5 July 2017; Forest Ecosystems STEF92 Technology Press: Sofia, Bulgaria, 2017; Volume 17, pp. 821-828, ISBN 978-619-7408-05-8. [CrossRef]

30. Farooq, I.; Shah, A.R.; Salik, K.M.; Ismail, M. Annual, Seasonal and Monthly Trend Analysis of Temperature in Kazakhstan during 1970-2017 Using Nonparametric Statistical Methods and GIS Technologies. Earth Syst. Environ. 2021. [CrossRef]

31. Kharlamova, N.F. Climatic variability of the Kulunda steppe. In Kulunda: Climate Smart Agriculture; Innovations in Landscape Research; Frühauf, M., Ed.; Springer: Berlin/Heidelberg, Germany, 2020; pp. 19-32. [CrossRef]

32. Kin, N.O. The Current State of Vegetation in the Zone of Influence of Gas Processing Enterprises of Western Kazakhstan; Ural Branch RAS: Orenburg, Russia, 2000; 21p. (In Russian)

33. Velts, N.Y. Assessment of the current state of vegetation in the Southern Urals (Orenburg region). United Sci. J. Mosk. Tezarus 2003, 2-3, 73-74.

34. Meshkov, V.V.; Baizakov, S.S.; Yeger, A.V.; Orozumbekov, A. Forest Rehabilitation in Kazakhstan; IURFO: Vienna, Austria, 2009; pp. 83-129. Available online: https: / / www.iufro.org (accessed on 29 October 2021).

35. Arkhipov, S.A. The Quaternary Period in Western Siberia; Nauka: Novosibirsk, Russia, 1971; 332p. (In Russian)

36. Chlachula, J. Pleistocene climates, natural environments and palaeolithic occupation of the Altai area, west Central Siberia. Quat. Int. 2001, 80-81, 131-167. [CrossRef]

37. Kharuk, V.I.; Im, S.T.; Dvinskaya, M.L.; Ranson, R.J.; Petrov, I.A. Tree wave migration across an elevation gradient in the Altai Mountains. Sib. J. Mt. Sci. 2017, 14, 442-452. [CrossRef] [PubMed]

38. Abukenova, V.S.; Nursultan, G.E. Soil Mesofauna of Pine Trees of the Kazakh Hills. 2012. Available online: https://articlekz. com/article/12034 (accessed on 29 October 2021).

39. Paramonov, E.; Rybkina, I. Band Altai forests in the period of climate warming. Sustain. Use 2017, 3, 33-39.

40. Zolotov, D.V. Influence of an alien element on taxonomic composition of steppe and forest-steppe flora in Altai region (Russia). Environ. Chang. Biol. Assess. 2008, 186, 337-341.

41. Zolotov, D.V.; Chernykh, D.V. Landscape-basin approach to the study of floristic diversity (heterogeneous catchments of steppe and forest-steppe zones of the Altai Region, Russia, as a case study). Acta Biol. Univ. Daugavp. 2015, 15, $383-392$.

42. Korchagin, A.A.; Lavrenko, E.M. Field Geo-Botany; Nauka: Moscow, Russia, 1960. (In Russian)

43. Mueller-Dombois, D.; Ellenberg, H. Aims and Methods of Vegetation Ecology; Wiley \& Sons: New York, NY, USA, 1974.

44. Serebryakov, I.G. Ecological Groups and Life Forms of Plants. Botany (Anat. Morphol. Plants) 1978, 3, 431-461. (In Russian)

45. Pavlov, N.V. Flora of Kazakhstan; Science: Alma-Ata, Russia, 1956-1966. (In Russian)

46. Wimmer, R.; Strumia, G.; Holawe, F. Use of false rings in Austrian pine to reconstruct early growing season precipitation. Can. J. For. Res. 2000, 11, 1691-1697. [CrossRef]

47. Mitchell, K. Quantative Analysis by the Point Centered Quarter Method; Department of Mathematics and Computer Science, Hobart and William Smith Colleges: Geneva, NY, USA, 2007.

48. Zakharov, V.K. Forest Taxation; Nauka: Moscow, Russia, 1967. (In Russian)

49. Sukachev, V.N. Guide to the Study of Forest Types; Selkhoizdat: Moscow, Russia, 1931. (In Russian)

50. ESRI 2020. Available online: https:/ / www.esri.com/en-us/about/about-esri/overview (accessed on 29 October 2021).

51. USGS 2020 Global Visualization Viewer [Electronic Resource]. Available online: http://glovis.usgs.gov/ (accessed on 18 April 2015).

52. Greenberg, J.A.; Dobrowski, S.Z.; Vanderbilt, V.C. Limitations on maximum tree density using hyperspatial remote sensing and environmental gradient analysis. Remote Sens. Environ. 2009, 113, 94-101. [CrossRef]

53. Ozanda, P. Vegetation cartography and phytoecological mapping in the laboratory of vegetation biology of the Alps, University of Grenoble, France. Geobot. Mapp. 1996, 17, 31-39.

54. Vinogradov, B.V. Fundamentals of Landscape Ecology; GEOS: Moskva, Russia, 1998; 418p. 
55. Zenkevich, Y.E.; Antonova, T.A.; Glushkov, I.V. Monitoring of forestry activity: Experience of using high and ultra-high resolution space imagery data. Earth Space 2009, 1, 17-22.

56. Bartalev, S.A. Study of the possibility of assessing the state of forest damaged by fires according to multispectral satellite measurements. In Modern Problems of Remote Sensing of the Earth from Space; Bartalev, S.A., Egorov, V.A., Eds.; Nauka: Moskva, Russia, 2010; Volume 7, pp. 16-20.

57. Soil Classification Working Group. Agriculture Canada Expert Committee on Soil Survey. In The Canadian System of Soil Classification; Research Branch Agriculture Canada Publication: Ottawa, ON, Canada, 1987; p. 164.

58. Fuchilo, Y.D.; Ryabukhin, A.Y.; Sbitnaya, M.V.; Kaydyk, V.Y.; Levin, S.V. Natural Restoration of the Ordinary Pine in the Conditions of the East Polesie of Ukraine. For. J. 2015, 1, 2-7. (In Russian)

59. Kabanova, S.A.; Danchenko, A.M.; Danchenko, M.A. Analysis of the spring and autumn plantings of forest crops of Pinus sylvestris 1. in ribbon-like pine forests of Irtysh Land (on example of state forest natural reserve "Semei Ormany"). Vestn. Orel State Agrar. Univ. 2017, 52-59.

60. Lanly, J.P. Deforestation and forest degradation factors. In Proceedings of the XII World Forestry Congress, Quebec City, QC, Canada, 21-28 September 2003; pp. 111-124.

61. Folke, C.; Carpenter, S.; Walker, B.; Scheffer, M.; Elmqvist, T.; Gunderson, L.; Holling, C.S. Regime shifts, resilience, and biodiversity in ecosystem management. Ann. Rev. Ecol. Evol. Syst. 2004, 35, 557-581. [CrossRef]

62. Lucier, A.; Ayers, M.; Karnosky, D.; Thompson, I. Forest responses and vulnerabilities to recent climate change. In Adaptation of Forests and People to Climate Change: A Global Assessment Report; Seppälä, R., Buck, A., Katila, P., Eds.; IUFRO World Series; International Union of Forest Research Organizations: Helsinki, Finland, 2009; Volume 22, pp. $29-52$.

63. Kissinger, G.; Herold, M.; de Sy, V. Drivers of Deforestation and Forest Degradation: A Synthesis Report for REDD+ Policymakers; Lexeme Consulting: Vancouver, BC, Canada, 2012.

64. Kleine, M.; Shaharuddin, G.; Kant, P. Case studies on measuring and assessing forest degradation: Addressing forest degradation in the context of joint forest management in Udaipur, India. In Forest Resources Assessment Paper 157; Food and Agriculture Organization: Rome, Italy, 2009.

65. Belov, A.A. Retrospective analysis of changes in the radial increment of pine trees in the ribbon-like pine forests of the Altai territory. Lesn. Khozyaistvo 2013, 3, 29-31.

66. Lioubimtseva, E.; Cole, R.; Adams, J.M.; Kapustin, G. Impacts of climate and land-cover changes in arid lands of Central Asia. J. Arid Environ. 2005, 62, 285-308. [CrossRef]

67. Kharlamove, N.; Revyakin, V. Regional Climate and Environmental Change in Central Asia. In Environmental Security and Sustainable Land Use-with Special Reference to Central Asia; Vogtmann, H., Dobretsov, N., Eds.; NATO Security through Science Series; Springer: Dordrecht, The Netherlands, 2006. [CrossRef]

68. Otto, O.V.; Redkin, A.V.; Yesimova, D.D. The Transformation of Forest Resources in the South of Western Siberia: Data from the Altai Krai; IOP Conference Series: Earth and Environmental Science 670 (2021) 012043; IOP Publishing: Bristol, UK, 2020. [CrossRef]

69. Ponomarev, E.I.; Kharuk, V.I. Wildfire occurrence in forests of the Altai-Sayan region under current climate changes. Contemp. Probl. Ecol. 2016, 9, 29-36. [CrossRef]

70. Zablotskii, V.I.; Barannik, L.P. Forest-growth conditions in fire-damaged forests in the south-western parts of ribbon-like pine forests of the Altai region. Lesn. Khozyaistvo 2000, 1, 52-54.

71. Kharlamova, N.; Sukhova, M.G.; Chlachula, J. Present Climate Development in Southern Siberia. A 50-Year Weather Observation Record, International Conference on Sustainable Development of Cross-Border Regions; IOP Conference Series; Earth and Environmental Science 395 (2019) 012027; IOP Publishing: Bristol, UK, 2019. [CrossRef]

72. Czerniawska, J.; Chlachula, J. Climate-change induced permafrost degradation in Yakutia. Arctic 2020, 73, 509-528. [CrossRef]

73. Chlachula, J.; Sukhova, M.G. Regional manifestations of present climate change in the Altai, Siberia. In International Proceedings of Chemical, Biological and Environmental Engineering and Applications, Proceedings of the ICEEA 2nd International Conference on Environmental Engineering and Applications, Shanghai, China, 19-21 August 2011; Xuan, L., Ed.; IACSIT Press: Singapore, 2011; Volume 17, pp. 134-139.

74. Sukhova, M.; Garns, E.; Chlachula, J. Bioclimatic Changes of the Trans-Border Region of Gorno Altai and Feedback of the Mountain Ecosystems. In Proceedings of the SWorld, International Conference Proceedings (Scientific Investigations and Their Practical Implications. Actual State and Ways of Development 2011), Odessa, Ukraine, 4-15 October 2013; Volume 51, pp. 30-34.

75. Rudaya, N.; Krivonogov, S.; Slowinski, M.; Cao, X.; Zhilich, S. Postglacial history of the Steppe Altai: Climate, fire and plant diversity. Quat. Sci. Rev. 2020, 249, 106616. [CrossRef] 